\title{
rbe
}

\section{Testing nonlinearities between Brazilian exchange rate and inflation volatilities*}

\author{
Christiane R. Albuquerque ${ }^{\dagger}$, Marcelo S. Portugal ${ }^{\ddagger}$
}

Contents: 1. Introduction; 2. The theoretical model; 3. Data; 4. Tests with unconditional volatility; 5. Tests with conditional variance - Bivariate GARCH; 6. Conclusions; A. Tables \& Graphs; B. Diagnostic Tests for the Bi-Garch Model.

Keywords: Exchange rate, inflation, volatility, Garch models

JEL Code: E31, F41.

There are few studies, directly addressing exchange rate and inflation volatilities, and lack of consensus among them. However, this kind of study is necessary, especially under an inflation-targeting system where the monetary authority must know well price behavior. This article analyses the relation between exchange rate and inflation volatilities using a bivariate GARCH model, and therefore modeling conditional volatilities, fact largely unexplored by the literature. We find a semi-concave relation between those series, and this nonlinearity may explain their apparently disconnection under a floating exchange rate system. The article also shows that traditional tests, with non-conditional volatilities, are not robust.

Existem poucos estudos, e pouco consenso, sobre a relação entre as volatilidades cambial e da inflação. Todavia, tais estudos são necessários, especialmente em um regime de metas de inflação onde a autoridade monetária deve conhecer detalhadamente o comportamento dos preços. Existem poucos estudos, e pouco consenso, sobre a relação entre as volatilidades cambial e da inflação. Todavia, tais estudos são necessários, especialmente em um regime de metas de inflação onde a autoridade monetária deve conhecer detalhadamente

\footnotetext{
${ }^{*}$ The authors would like to thank Carlos H. V. Araújo (Banco Central do Brasil - BCB), Joaquim de Andrade (UNB), Maria da Glória Araújo (BCB), Roberto Camps de Moraes (UFRGS), Sergio Alves (BCB) and an anonymous referee for their comments on a previous version. The authors also would like to thank Angelo Fasolo and Eui Jung (both from BCB) for their valuable contributions to this paper. The remaining errors are the authors' responsibility. The views expressed in this work are those of the authors and do not necessarily reflect those of the Central Bank of placecountry-regionBrazil or its members.

${ }^{\dagger}$ Economist, Research Department of the Central Bank of placecountry-regionBrazil. E-mail: christiane . albuquerque $@ b c b$. gov.br

${ }^{\ddagger}$ Professor of Economics, Universidade Federal do Rio Grande do Sul (UFRGS), and associate researcher of CNPq. Email: msp@ ufrgs.br
} 
o comportamento dos preços. Este artigo analisa a relação entre aquelas volatilidades usando um modelo Garch bivariado, modelando, portanto, as volatilidades condicionais, enfoque pouco explorado pela literatura. Encontramos uma relação semi-côncava entre as séries, e esta não-linearidade pode explicar $o$ aparente descolamento das mesmas em períodos de regime cambial flutuante. 0 artigo também mostra que os testes tradicionais, com volatilidades não-condicionais, não são robustos.

\section{INTRODUCTION}

The study of exchange rate volatility's effects should be important for monetary policy decisions, since higher volatility means higher uncertainty, which may affect inflation expectations, a crucial variable in monetary policy decisions. Although the literature about the impact of exchange rate volatility on inflation is not as extensive as the one available for its pass-through to prices, some authors highlight such relation. Whether the impacts are significant or not remains controversial: some authors defend the absence of connection between exchange rate and macroeconomic variables volatilities while others state the opposite. ${ }^{1}$ According to the first group, exchange rate volatility is not important to macroeconomic variables, since empirical evidence shows a substantial increase in the former during floating exchange rate regimes, while the latter did not present a similar rise in their volatilities. ${ }^{2}$ The second group finds evidence of such relation, being either positive or negative, in studies conducted under different aims and approaches.

This paper seeks to check for the existence of a relation between exchange rate and inflation volatilities for the Brazilian case, and our conclusions in this paper could be classified in the second group, related especially with the findings of Dixit (1989) and Seabra (1996). By developing an optimization model for the firm, the first author shows that trade flows and prices would depend on investment made on a future basis and, consequently, on both expectations and higher moments of the distributions involved. In consequence, the macroeconomic environment affects the pattern of price changes. Hence, not only the level of the devaluation but also the volatility of the exchange rate would affect its pass-through to prices. Seabra (1996), on its turn, uses a model of intertemporal optimization with asymmetric adjustment costs and shows that the critical value that leads a firm to invest is a function of uncertainty. If uncertainty is high, the optimal decision will be to wait before making a movement (wait-and-see strategy), even with the exchange rate at a level that makes investment profitable. This attitude impacts on aggregate supply and, therefore, on inflation.

Other interesting works are those of Hausmann et al. (2001), who find a negative and significant correlation in their tests between pass-through and measures of volatility, and Smith (1999), where a reduction in inflation volatility as a result of an increase in exchange rate volatility was found in approximately $31 \%$ of the cases. The welfare approach recalled by Ghosh et al. (1997) and by Sutherland (2005) are also worth mentioning. The former show that inflation volatility is lower under floating and intermediate exchange rate regimes for countries with low inflation, while the latter show that the sign of relation between exchange rate and inflation volatilities will depend on the model's parameters.

In this paper, we adopt a more sophisticated econometric methodology than those applied so far in literature: instead of constructing exogenous volatility series (by computing the volatility of subsamples

\footnotetext{
${ }^{1}$ For the first group, see, for instance, Krugman (1988), Obstfeld and Rogoff (2000), Baxter and Stockman (1988), Flood and Rose (1995), Rogoff (2001) and Duarte and Stockman (2002). For the second, Calvo and Reinhart (2000a,b), Barkoulas et al. (2002), Wei and Parsley (1995), Andersen (1997), Smith (1999), Engel and Rogers (2001), Devereux and Engel (2003), Chen (2004), Barone-Adesi and Yeung (1990), Bleaney (1996), and Bleaney and Fielding (2002).

${ }^{2}$ Obstfeld and Rogoff (2000) call the apparently disconnection between the exchange rate volatility and macroeconomic fundamentals.
} 
or rolling windows) we apply a bivariate GARCH model, working with conditional volatility series. The purpose of this procedure is to adopt a measure not sensitive to individual selection criteria. Apart from that, by modeling the conditional heteroskedasticity of exchange rates, it is also a more suitable econometric technique. One of the contributions proposed by this paper is to verify whether exchange rate volatility has impacts strong enough on inflation so that the monetary authority should monitor it, an approach still scarce, especially in placecountry-regionBrazil. The other one is to show that traditional tests are not robust for this type of study and that Garch-type models are more suitable for such analysis.

The paper is divided into six sections, including this introduction. Section 2 introduces the theoretical model that led to the econometric tests, while data is presented in section 3 . The results obtained by the use of traditional methods (i.e.: unconditional variance series) are presented in section 4 . Section 5 shows the results of the bivariate GARCH model, and section 6 concludes.

\section{THE THEORETICAL MODEL}

We derive an equation relating inflation and exchange rate volatilities to test for the existence of a significant relation between them. The approach to achieve such equation is based on Bleaney and Fielding (2002), with slight modifications. The government has a utility function $\mathrm{Z}$, of the Barro and Gordon (1983) type, to be maximized. $\mathrm{Z}$ is given by equation 1 , which represents the case where the government of a country faces a trade-off between price stabilization and output growth above its equilibrium level.

$$
Z=-0.5 \pi^{2}-0.5 b\left(y-y^{*}-k\right)^{2}
$$

Where $\pi$ is inflation, $y$ is the output level and $y^{*}$ is potential output. The term $b>0$ is incorporated by the authors, meaning the relative weight given to output, and $k>0$ represents the inflationary bias of the government. The presence of $b$ and $k$ comes from the assumption that a government could eventually attribute a higher weight to output growth to the detriment of price stability.

The restriction imposed by the authors upon function $Z$ consists of an expectations-augmented Phillips Curve, including the exchange rate. Here, we have the first difference to the model of Bleaney and Fielding (2002) since we will focus not on the real but on the nominal exchange rate. Our restriction will be a Phillips Curve for an open economy, including both the forward-looking and the backwardlooking term, as described in equation 2 below.

$$
\pi_{t}=a_{0} \pi_{t}^{e}+a_{1} \pi_{t-1}+a_{2}\left(y-y^{*}\right)+a_{3} \Delta\left(p_{t}^{e x t}\right)+a_{4} s_{t}+\epsilon_{t}
$$

where $p_{t}^{e x t}$ is the foreign price level, $s_{t}$, the nominal exchange rate and $\pi_{t}^{e}$ the inflation expectation between period $t$ and period $t+1$.

We also assume the exchange rate following a random walk, as in many partial equilibrium studies. Thus, we have

$$
s_{t}=s_{t-1}+\eta_{t} \quad \eta_{t} \sim N\left(0, \sigma_{\eta}^{2}\right)
$$

applying (2) and (3) to (1), and obtaining the first-order condition for the maximization of $Z$ with respect to $\pi$, we have

$$
\pi=\beta a_{0} \pi_{t}^{e}+\beta a_{1} \pi_{t-1}+\beta a_{3} \Delta p_{t}^{e x t}+\beta a_{4} s_{t-1}+\beta a_{4} \eta_{t}+\beta \epsilon_{t}+K^{\prime}
$$

where $\beta=\frac{b}{a_{2}^{2}+b}$ and $K^{\prime}=-\beta a_{2} k$.

Some assumption also must be made concerning the behavior of $\pi_{t}^{e}$. We, then, consider that inflation expectations are of the form:

$$
\pi_{t}^{e}=\pi_{t-1}+\nu_{t}
$$


Thus, substituting (5) in (4) we get that

$$
E[\pi]=\left(\beta a_{0}+\beta a_{1}\right) \pi_{t-1}+\beta a_{3} \Delta p_{t}^{e x t}+K^{\prime}
$$

The terms $\epsilon_{t}, \eta_{t}$ and $\nu_{t}$ are independents, therefore, inflation variance given by

$$
\operatorname{var}(\pi)=\beta^{2} a_{0}^{2} E\left(v_{t}\right)^{2}+\beta^{2} a_{4}^{2} E\left(\eta_{t}\right)^{2}+\beta^{2} E\left(\epsilon_{t}\right)^{2}
$$

But, from (2), we have that $E\left(\epsilon_{t}\right)^{2}$ is the inflation variance. Hence,

$$
\operatorname{var}(\pi)=\mu_{0} E\left(v_{t}\right)^{2}+\mu_{1} E\left(\eta_{t}\right)^{2}
$$

where $\mu_{0}=\frac{\beta^{2} a_{0}^{2}}{\left(1-\beta^{2}\right)}$ and $\mu_{1}=\mu_{0} * \frac{a_{4}^{2}}{a_{0}^{2}}$

Inflation variance is, therefore, a function of $\nu_{t}$ (the variance of the shock expected in $t$ in relation to $t-1$ inflation) and of $\eta_{t}$ (variance of the exchange rate process).

With (8), we may test for a relation between volatilities and we aim to do that by using a multivariate GARCH model. However, due to the small sample available - from the beginning of the floating exchange rate system in placecountry-regionBrazil, i.e., January, 1999 to September, 2004 - the large number of terms to be estimated does not allow us to estimate a multivariate GARCH model with three variables. Aside from that, the inflation expectations research published by the Central Bank of placecountry-regionBrazil started only on April, 2000, reducing our sample even further. Therefore, we will assume that the variance measured by $\nu_{t}$ is constant and, hence, equation 8 becomes:

$$
\operatorname{Var}(\pi)=\mu_{0}^{\prime}+\mu_{1} \operatorname{var}\left(\eta_{t}\right),
$$

where $\mu_{0}^{\prime}=\mu_{0}+\operatorname{var}\left(\nu_{t}\right)$ is the new constant.

Although the assumption that $\nu_{t}$ is constant is strong, we may consider it. Table 1 shows the result of a regression of $\pi_{t}^{e}$ against $\pi_{t-1}$ and a constant. If our hypothesis that the shock expected to $t+1$ in comparison with $t-1$ is, on average, constant, then the residuals of this equation should be homoskedastic. As we may see, we accept the null hypothesis of homoskedasticity, which supports our assumption that $\nu_{t}$ is constant. ${ }^{3}$ Besides, if we compute $v_{t}=\pi_{t}^{e}-\pi_{t-1}$ one can notice that almost the entire series is within the interval of one standard deviation from the mean, as shown in Graph 1 , with the longest period in which it was outside that band being from December 2002 to April 2003.

The data for $\pi_{t}^{e}$ refer to the average market expectations for IPCA ${ }^{4}$ inflation in month $t+1$ as in the last business day of month $t-1$, and they are published by the Investor Relations Group (Gerin) from the Central Bank of Brazil. ${ }^{5}$

Table 1 - Estimation of Equation $\pi_{t}^{e}=c+\pi_{t-1}$

\begin{tabular}{|c|c|c|c|c|}
\hline \multicolumn{5}{|c|}{ method: OLS; sample: 2000:03 to 2004:10 } \\
\hline Variable & Coefficient & Standard deviation & $t$-statistics & $p$-value \\
\hline$\pi_{t-1}$ & 0.1593 & 0.0542 & 29.385 & 0.0049 \\
\hline$C$ & 0.4463 & 0.0555 & 80.351 & 0.0000 \\
\hline MA(1) & 0.6576 & 0.1145 & 57.452 & 0.0000 \\
\hline$R^{2}$ & 0.4584 & \multicolumn{2}{|c|}{ Durbin-Watson } & 18.755 \\
\hline adjusted $R^{2}$ & .4376 & White Test for homoskedasticity: (p-value) & 0.4354 \\
\hline
\end{tabular}

\footnotetext{
${ }^{3}$ Equivalent tests to $\pi_{t}$ and $s_{t}$ from equations 2 and 3 accepted the alternative hypothesis of heteroskedasticity

${ }^{4}$ Index of consumer prices considered by the Central Bank in the inflation targeting.

${ }^{5}$ http : //www4.bcb.gov.br/?FOCUSERIES
} 
Figure 1 - Evolution of $\nu_{t}=\pi^{e}-\pi_{t-1}$

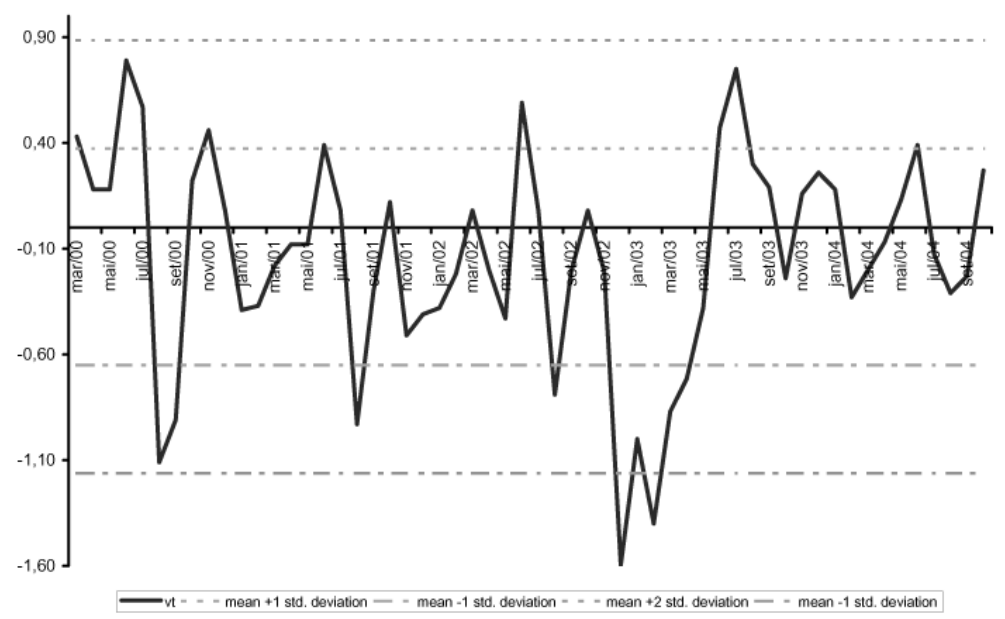

\section{DATA}

Our sample was computed on a monthly basis, from 1999:01 to 2004:09, and data used in our estimations were the following:

(a) Price Index: Extended Consumer Price Index (IPCA), consumer price index published by the Brazilian Institute of Geography and Statistics (IBGE), ${ }^{6}$ December/1993=100 and considered by the Central Bank of Brazil as the reference index in the inflation targeting regime;

(b) Exchange Rate: Exchange rate R\$/US\$, selling prices, monthly average;

(c) External Prices: Producer price index (PPI), published by the Bureau of Labour Statistics ${ }^{7}$ (commodities, final goods).

(d) GAP: output gap. It was computed by subtracting the industrial production series published by IBGE (used as a proxy for monthly GDP) from the trend obtained by the Hodrick-Prescott filter.

All series were seasonally adjusted by the X-12 method and, afterwards, taken in logarithms (ln). Next, unit root tests were performed. All series, except for gap have unit roots, as shown in Table 9 in the appendix A, and, therefore, they were taken in first differences. The series in first difference of Price Index, Exchange Rate and External Prices are henceforth referred to as $I P C A, E$ and $P P I$, respectively.

\section{TESTS WITH UNCONDITIONAL VOLATILITY}

As a first step, we followed the main procedures found in literature and made tests using unconditional volatilities. In such cases, volatility is more often computed by the standard deviation from the

${ }^{6}$ http://www.ibge.gov.br

${ }^{7}$ http://www.bls.gov/data 
mean in small samples, or by the variance within them. These samples are given either by splitting the series into small subsamples or by adopting rolling windows. ${ }^{8}$

In this paper, we opted for three different methods to calculate the unconditional volatility series. The first one is constructed by computing the standard deviation from the mean in rolling windows with $4,6,8$ and 12 observations in each window (series are computed as the first difference of the natural logarithm of the variable on a monthly basis). The second one considers the variances, instead of the standard deviation. Finally, we tested a VAR between the price index (IPCA) and the exchange rate $(E)$ and analyzed the resulting variance decomposition.

\subsection{Rolling Windows with standard deviations}

The volatilities computed by the standard deviations are presented in Graphs 2 and 3, where $E \_i$ and $I P C A_{-} i$ are the volatilities of $\mathrm{E}$ and IPCA, respectively, within a window of size $i$. It is possible to note that the series are sensitive to the size of the window. As Table 10 shows, the unit root test for $I P C A_{-} i$ is also affected by window size: $I P C A_{-} 4$ is stationary and so is $I P C A \_6$, although we reject the presence of unit roots in the former at a level of significance of $10 \%$. However, $I P C A \_8$ and $I P C A \_12$ have unit roots. Since $E_{-} i$ is always stationary, we computed the first differences of $I P C A_{-} 8$ and $I P C A_{-} 12$, named $d_{-} I P C A_{-} 8$ and $d_{-} I P C A_{-} 12$, respectively.

Figure 2 - Variances of IPCA (standard deviations from the mean) - Rolling Windows

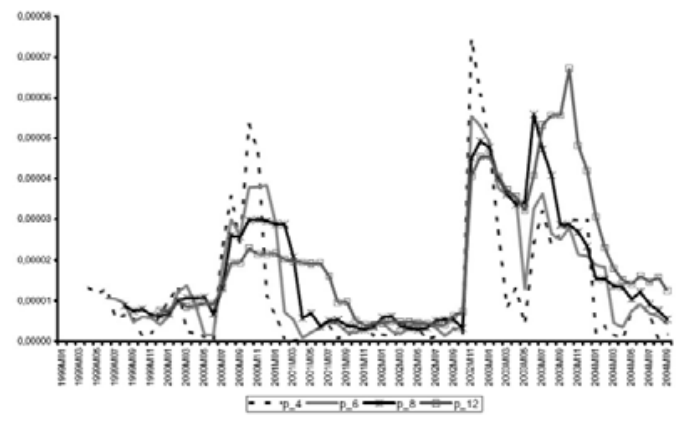

Figure 3 - Variances of E (standard deviations from the mean) - Rolling Windows

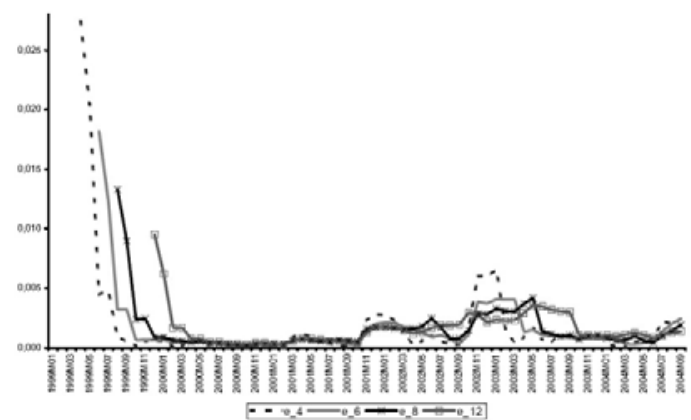

The estimation results also are very sensitive to window size, as it can be seen in tables 11 to 14 in appendix A. ${ }^{9}$ In the four-month window, the lagged terms of a variable in its respective equation and the effect of inflation variance on exchange rate variance are considered to be statistically significant. With regard to the six-month window, there are significant cross-terms. However, the Wald test shows

\footnotetext{
${ }^{8}$ Carrera and Bastourre (2004) attribute the few macroeconomic studies about volatility to the lack of a pattern to define or to measure volatility. According to them, the use of rolling windows, instead of subsamples, has the advantage of reducing information loss (resultant from the reduced sample size). However, this procedure is also limited due to the difficulty in determining the ideal number of observations in a window. In addition, it may imply a high correlation between the computed series, which may affect the quality of estimators, and alter the true relation between the volatilities. For instance, once the exchange rate regime varies over time, a certain window may contain two different regimes.

${ }^{9}$ The number of lags in each VAR was chosen by taking into consideration the information criteria, absence of residual autocorrelation (LM test), absence of correlation between variables, and parsimony. In all models the dummy variable $d 2002 \_M 11$ - which assumes the unity value for November 2002 - was included, since in all series there is a peak in that month, probably associated with the political crisis. Its inclusion allowed us to correct problems of residual autocorrelation or correlation between the variables found in the model. For similar reasons, the dummy variables d1999 in the four-month window and $d 2003 \_M 10$ in the 12-month window were included. The latter assumes the unity value for April and May 1999 (peak in $E \_4$ ) while the former equals the unity value for October 2003 (peak in IPCA_12).
} 
that the sum of the lagged coefficients of $E \_6$ in the IPCA_6 equation is not statistically different from zero, and the same happens to the lagged coefficients of $I P C A \_6$ in the $E \_6$ equation. Only the dummy and first lag of a variable are significant in the equation. In the eight-month window, only $E \_8(-1)$ in the equation for $E \_8$ is significant, while only the dummy is significant in the $D_{-} I P C A \_8$ equation. However, in this VAR, the correlation between $I P C A \_8$ and $E \_8$ equals -0.43 , which may jeopardize the OLS estimation. Finally, the VAR between $d_{-} I P C \bar{A} \_12$ and $E \_12$ reports the coefficient of $E_{-} 12(-1)$ as the only significant one in the $E_{-} 12$ equation. $E_{-}-12(-1), \bar{E} \_12(-6)$ and $E_{-} 12(-7)$ are significant in the d_IPCA_12 equation and, according to the Wald test, their sum is statistically different from zero at a $10 \%$ level.

In sum, the relation between those two endogenous variables is sensitive to window size. Depending on the size selected, we may accept or reject that the exchange rate variance affects inflation variance and the other way round, as well as accept or reject that lagged values of inflation variance will affect it.

\subsection{Rolling Windows with variances}

Once again, we have series that are very sensitive to window size, as shown in Graphs 4 and 5 ( $p i$ and $e i$ are the volatility series for IPCA and E, respectively, computed as the variance of the sample inside the window). Concerning stationarity, the only difference from the standard deviation case is that the variance of IPCA in the six-month window is not stationary (table 15 in the appendix A). Hence, we took the first difference of $p 6, p 8$ and $p 12$, and named them as $d p 6, d p 8$ and $d p 12$, respectively.

Tables 16 to 19 in the appendix A show the results of the four estimated VARs. ${ }^{10}$ For the fourmonth window VAR, only the lagged terms of each variable are significant and, differently from the previous case, the volatility of IPCA would not affect the exchange rate volatility. As for the six-month window, contrary to what was observed in the standard deviation case, the only significant terms are the dummy and the first lag of the exchange rate volatility in its own equation. In the eight-month window, we do not find the correlation problem we found before but, again, the only term that is significant is $e 6(-1)$ in the equation for the exchange rate variance. Finally, the VAR between $d p 12$ and $e 12$ indicates $e 12(-1)$ as the only significant variable in the equation for $e 12$. In the equation for inflation variance, the coefficients for $e 12(-1)$ and $e 12(-2)$ are significant and the Wald test shows that their sum is statistically different from zero at a $10 \%$ level.

In sum, we notice that the results differ from the ones obtained in the case with standard deviations concerning unit root tests, the number of lags in the VAR and the significance of some variances. None of the models showed that inflation volatility is affected by its lagged term, differently from what happens to exchange rate volatility. When it comes to cross-terms, we find that exchange rate volatility is significant in explaining inflation volatility in the 12-month windows. Hence, one can realize that results are sensitive not only to window size but also to the method chosen to compute volatility. In addition, since there are lagged effects in the case of exchange rate variance, we reinforce the adequacy of investigating a GARCH-type model.

\subsection{Variance decomposition in a VAR model}

The last exercise performed in this section was to test a VAR between the price index and the exchange rate and to analyze variance decomposition. Since both series have unit roots, as shown in Table 1, we first tested for the presence of cointegration vectors. As shown in Table 20 in the appendix A, the Trace and Eigenvalue tests do not accept the null hypothesis of presence of a cointegration vector. ${ }^{11}$

\footnotetext{
${ }^{10}$.D2002_M11 was included for the six-month window case

${ }^{11}$ The conclusion is the same if we consider only one lag.
} 
Figure 4 - Variances of IPCA (variances) - Rolling Windows

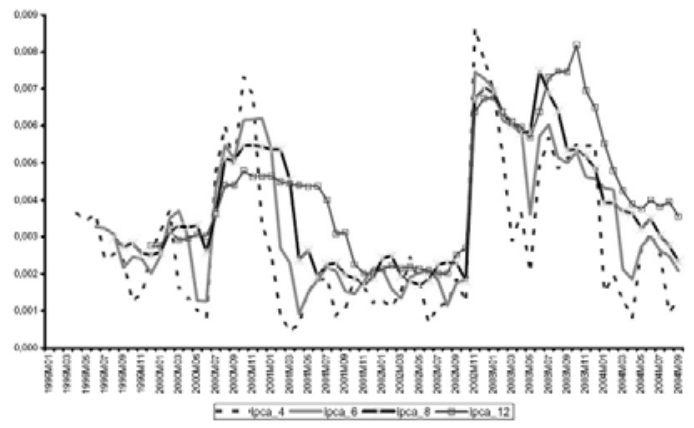

Figure 5 - Variances of E (variances) - Rolling Windows

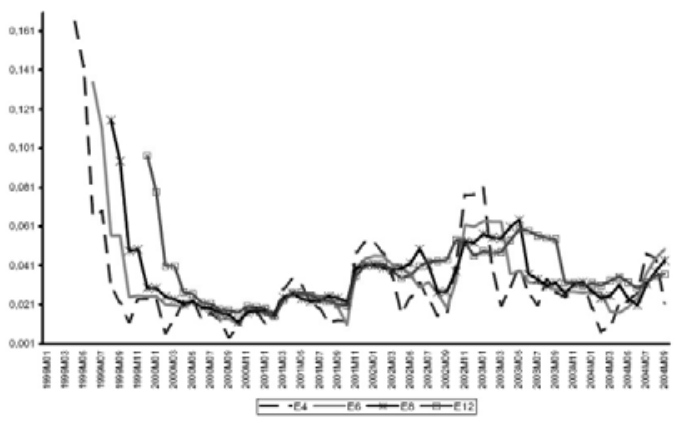

For this reason, we will test a VAR between the first differences of price index (IPCA) and exchange rates (E).

In the variance decomposition factorization by Cholesky method, we chose E preceding IPCA, since we consider the former to be more exogenous than the latter. The Granger test may be used to give further support in the ordering decision (table 21 in the appendix A. However, since the correlation between the residuals is low $(-0.17<|0.20|)^{12}$ the order does not have significant effects over the results. Table 22 shows the VAR results, while Table 23 presents the variance decomposition.

By analyzing the variance decomposition in table 23 , we find that about $3 \%$ of the movements in IPCA in $t+1$ may be explained by shocks in $\mathrm{E}$ in period $\mathrm{t}$. There are increasing accumulated effects over time, and shocks in E explain around $42 \%$ of the movements in IPCA after 12 months. A shock in IPCA, in its turn, does not have an immediate effect on the sequence of $\mathrm{E}$, however it has lagged effects, although on a smaller scale.

Graphs 6 to 9 show these decompositions over time, as well as the interval of \pm 2 standard errors. We notice that shocks to the variables have positive effects on their sequences, and apart from the impact of IPCA on E, they are different from zero. Therefore, we cannot rule out the hypothesis that shocks to the exchange rate - represented by $\eta_{t}$ in equation 3 - might affect inflation.

Figure 6 - Percent E variance due to E

Figure 7 - Percent IPCA variance due to E
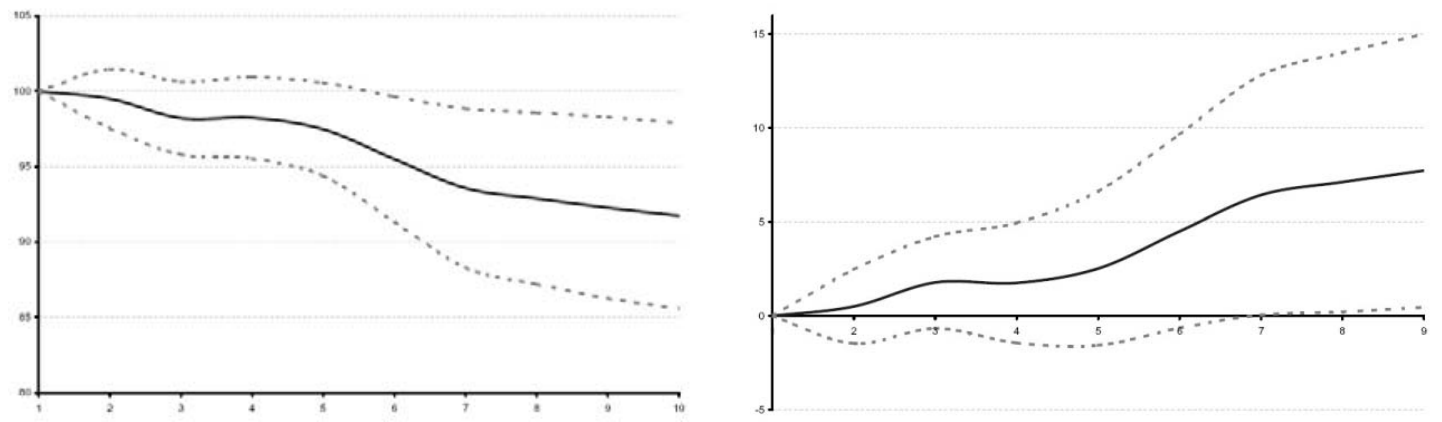

\footnotetext{
${ }^{12}$ Enders (1995) suggests, as a rule-of-thumb, that a correlation between residuals of the variables $<|0.2|$ is not strong enough to affect the results in the Cholesky decomposition.
} 
Figure 8 - Percent IPCA variance due to $\mathrm{E}$

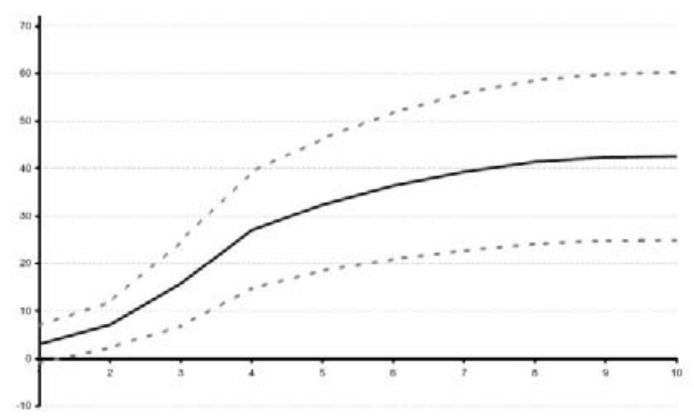

Figure 9 - Percent IPCA variance due to IPCA

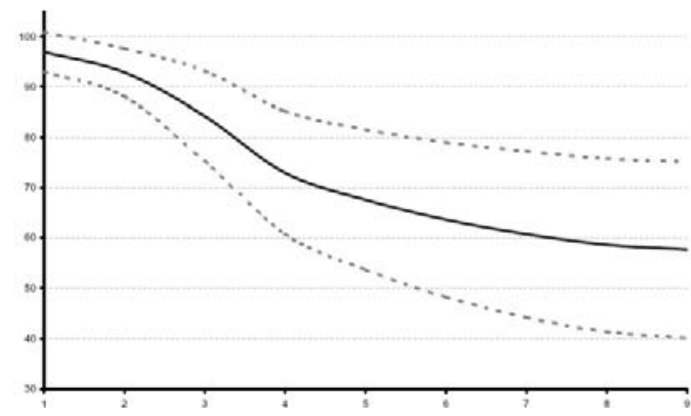

Based on the results presented in this section, we may infer that the traditional measures used to verify whether there is a relation between the volatilities of exchange rate and macroeconomic variables (standard deviations or variances in subsamples) yield results that are sensitive to the subsample size, leading us to accept or reject the significance of the relation according to the window size we are working with.

The variance decomposition, in its turn, indicates that shocks to the exchange rate affect inflation variance. Since volatility is also a measure of uncertainty, this result sounds more intuitive than some of those presented before: if the exchange rate affects inflation and has delayed effects (incomplete exchange rate pass-through in the short run), shocks to that variable will affect the uncertainty about future inflation. Besides, an adequate exchange rate model must consider the presence of conditional heteroskedasticity, as illustrated in Table 24 in the appendix. In this case, it is necessary to generate volatility series for both variables in the same way - hence, to consider conditional variance for both and not simply compare the variance series obtained from a GARCH $(p, q)$ model for the exchange rates with an exogenous measure of inflation volatility. Furthermore, we show that variance decomposition reports that shocks to the IPCA affect its variance, just as well as some of the results obtained in the rolling window procedure show us that IPCA volatility is affected by its past values, reinforcing the application of the test for a bivariate GARCH model with E and IPCA.

\section{TESTS WITH CONDITIONAL VARIANCE - BIVARIATE GARCH}

Testing a GARCH model requires, first, some assumption about the mean equations. We considered, therefore, three different cases. The first one is consisted of only lagged terms of each variable; the second, of a Phillips Curve for the IPCA equation (according to equation 2 in Section 2) and the lagged values for the exchange rate; the third, of the Phillips Curve for the IPCA and a random walk with drift for the exchange rate (equation 3 in Section 2). According to unit root tests previously performed, both variables were considered in first differences of their logarithms. Considering both the crosscorrelograms and OLS models, we chose the number of lags in the equations for IPCA and exchange rate. ${ }^{13}$ With regard to variance specifications, we tested five different options: diagonal-Vec (Bollerslev et al., 1988), constant correlation (CCORR, from Bollerslev 1990), full parameterization (Vec), the BEKK restriction (Engle and Kroner, 1993) and the dynamic conditional correlation (DCC, from Engle 2002). Only under the BEKK restriction convergence was achieved, and we consider some reasons for that further ahead in this section.

The general form of mean, variance and covariance equations under the BEKK model are:

${ }^{13}$ When they pointed to different number of lags, we tested the highest one. 
Mean equations

$$
\begin{aligned}
I P C A & =\delta_{0}+\delta_{1} I P C A_{t-1}+\delta_{2} E_{t-1}+\delta_{3} E_{t-2}++\delta_{4} G A P_{t-2}+\delta_{5} P P I_{t-1}+\epsilon_{1, t} \\
E & =\gamma_{0}+\gamma_{1} E_{t-1}+\gamma_{2} E_{t-2}+\epsilon_{2, t}
\end{aligned}
$$

Variance and Covariance equations ${ }^{14}$

$$
\begin{aligned}
h_{11} & =c_{11}+a_{11}^{2} \epsilon_{1, t-1}^{2}+2 a_{11} a_{21} \epsilon_{1, t-1} \epsilon_{2, t-1}+a_{21}^{2} \epsilon_{2, t-1}^{2}+g_{11}^{2} h_{11, t-1}+2 g_{11} g_{21} h_{12, t-1}+g_{21}^{2} h_{22, t-1} \\
h_{22} & =c_{22}+a_{12}^{2} \epsilon_{1, t-1}^{2}+2 a_{12} a_{22} \epsilon_{1, t-1} \epsilon_{2, t-1}+a_{22}^{2} \epsilon_{2, t-1}^{2}+g_{12}^{2} h_{11, t-1}+2 g_{12} g_{22} h_{12, t-1}+g_{22}^{2} h_{22, t-1} \\
h_{12} & =c_{21}+a_{11} a_{12} \epsilon_{1, t-1}^{2}+\left(a_{12} a_{22}+a_{21} a_{12}\right) \epsilon_{1, t-1} \epsilon_{2, t-1}+a_{21} a_{22} \epsilon_{2, t-1}^{2} \\
& +g_{12} g_{11} h_{11, t-1}+\left(g_{11} g_{22}+g_{12} g_{21}\right) h_{12, t-1}+g_{21} g_{22} h_{22, t-1}
\end{aligned}
$$

In order to make the analysis clearer, we renamed the coefficients above as:

$$
\begin{aligned}
c_{11} & =\alpha_{0} ; a_{11}^{2}=\alpha_{1} ; 2 a_{11} a_{21}=\alpha_{2} ; a_{21}^{2}=\alpha_{3} ; g_{11}^{2}=\alpha_{4} ; 2 g_{11} g_{21}=\alpha_{5} ; g_{21}^{2}=\alpha_{6} \\
c_{22} & =\beta_{0} ; a_{12}^{2}=\beta_{1} ; 2 a_{12} a_{22}=\beta_{2} ; a_{22}^{2}=\beta_{3} ; g_{12}^{2}=\beta_{4} ; 2 g_{12} g_{22}=\beta_{5} ; g_{22}^{2}=\beta_{6} \\
c_{21} & =\mu_{0} ; a_{11} a_{12}=\mu_{1} ; a_{12} a_{22}+a_{21} a_{12}=\mu_{2} ; a_{21} a_{22}=\mu_{3} ; g_{12} g_{11}=\mu_{4} ; g_{11} g_{22}+g_{12} g_{21} \\
& =\mu_{5} ; g_{21} g_{22}=\mu_{6}
\end{aligned}
$$

Hence, the variance and covariance equations can be rewritten as:

$$
\begin{aligned}
& h_{11}=\alpha_{0}+\alpha_{1} \epsilon_{1, t-1}^{2}+\alpha_{2} \epsilon_{1, t-1} \epsilon_{2, t-1}+\alpha_{3} \epsilon_{2, t-1}^{2}+\alpha_{4} h_{11, t-1}+\alpha_{5} h_{12, t-1}+\alpha_{6} h_{22, t-1} \\
& h_{22}=\beta_{0}+\beta_{1} \epsilon_{1, t-1}^{2}+\beta_{2} \epsilon_{1, t-1} \epsilon_{2, t-1}+\beta_{3} \epsilon_{2, t-1}^{2}+\beta_{4} h_{11, t-1}+\beta_{5} h_{12, t-1}+\beta_{6} h_{22, t-1} \\
& h_{12}=\mu_{0}+\mu_{1} \epsilon_{1, t-1}^{2}+\mu_{2} \epsilon_{1, t-1} \epsilon_{2, t-1}+\mu_{3} \epsilon_{2, t-1}^{2}+\mu_{4} h_{11, t-1}+\mu_{5} h_{12, t-1}+\mu_{6} h_{22, t-1}
\end{aligned}
$$

For each case, different simulations were made changing the convergence criteria and the number of iterations. Therefore, it is possible that, for each case, we ended up with more than one result achieving convergence. When this occurred, the choice was made based on the following criteria: LM and the ARCH-LM tests (i.e. absence of residual serial correlation and of arch-type residuals), calculation of the eigenvalues to assure that the condition of covariance stationarity was respected (see Engle and Kroner (1993) for further details on conditions and tests), and, when all the previous were respected, we chose the result that maximized, for the case considered, the likelihood function. The final results are presented in table 2 .

By analyzing Table 2 , we notice that the results for the mean equations are quite similar, as well as the values in the variance equation for cases (1) and (2). Case (3) differs from the other two but, since that model has $\mathrm{ARCH}$ residuals for the equation of $\mathrm{E}$ and serial correlation of residuals for both mean equations, ${ }^{15}$ it cannot be considered as a good model.

Comparing the variance equations in cases (1) and (2), we see that the differences lie in the signs of $g_{12}$ and $g_{22}$, in the values of $a_{11}, a_{22}$ and $a_{12}$ and in the significance of coefficients $\mu_{1}, \beta_{1}$ and $\beta_{2}$, that is, the impact of $\epsilon_{1, t-1}^{2}$ on the conditional variance of $E$ (first difference of the exchange rate) and in the covariance and impact of $\epsilon_{1, t-1}^{2} \epsilon_{2, t-1}^{2}$ on the conditional covariance of $E$.

${ }^{14}$ Variance and covariance equations are from Engle and Kroner (1993), equation 2.3, pages 5 and 6, without suppressing the GARCH terms.

${ }^{15}$ We could not find any model that removed the autocorrelation in the mean equation of the exchange rate, which was expected since there are no lagged terms in that equation. 
Table 2 - Bivariate GARCH Results (Monthly data from 1999:01 to 2004:09)

\begin{tabular}{|c|c|c|c|c|}
\hline & Variables & Case 1 & Case 2 & Case $3 a$ \\
\hline Function Value & & 5.485 .888 .337 & 5.587 .008 .734 & 5.480 .509 .755 \\
\hline \multirow{12}{*}{ Equation for IPCA } & Constant & $0.00282329^{*}$ & $0.00197323^{*}$ & $0.0011409^{*}$ \\
\hline & \multirow[b]{2}{*}{$I P C A_{t-1}$} & (0.0005596) & (0.00050458) & $(0.00051313)$ \\
\hline & & $0.55715402^{*}$ & $0.57849083^{*}$ & $0.68315183^{*}$ \\
\hline & \multirow[b]{2}{*}{$E_{t-1}$} & $(0.07376155)$ & $(0.0609667)$ & $(0.05967424)$ \\
\hline & & - & $0.03863824^{*}$ & $0.06380358^{*}$ \\
\hline & \multirow[b]{2}{*}{$E_{t-2}$} & & $(0.00980401)$ & $(0.00779833)$ \\
\hline & & - & -0.00073484 & -0.00920641 \\
\hline & \multirow[b]{2}{*}{$G A P_{t-2}$} & & $(0.00964137)$ & $(0.0073217)$ \\
\hline & & - & $0.01673604^{* *}$ & $0.01552899^{* *}$ \\
\hline & \multirow{3}{*}{$P P I_{t-1}$} & & $(0.00977043)$ & $(0.0095768)$ \\
\hline & & - & $0.09498593^{* *}$ & $0.10285839^{*}$ \\
\hline & & & $(0.05367548)$ & $(0.05499651)$ \\
\hline \multirow[t]{6}{*}{ Equation for $\mathrm{E}$} & Constant & 0.00669639 & $0.01229489^{*}$ & $0.01917512^{*}$ \\
\hline & \multirow[b]{2}{*}{$E_{t-1}$} & $(0.00424251)$ & $(0.0043067)$ & $(0.00534423)$ \\
\hline & & $0.8094822^{*}$ & $0.60752556^{*}$ & - \\
\hline & \multirow{3}{*}{$E_{t-2}$} & $(0.11426506)$ & $(0.12549928)$ & - \\
\hline & & $-0.22750191^{* *}$ & -0.16772685 & - \\
\hline & & (0.13597143) & (0.10694474) & \\
\hline \multirow[t]{7}{*}{ Conditional variance of IPCA } & $\alpha_{0}$ & 0 & 0 & 0 \\
\hline & $\alpha_{1}$ & + & + & + \\
\hline & $\alpha_{2}$ & + & + & + \\
\hline & $\alpha_{3}$ & + & + & + \\
\hline & $\alpha_{4}$ & 0 & 0 & 0 \\
\hline & $\alpha_{5}$ & 0 & 0 & 0 \\
\hline & $\alpha_{6}$ & 0 & 0 & 0 \\
\hline \multirow[t]{7}{*}{ Conditional variance of $\mathrm{E}$} & $\beta_{0}$ & 0 & 0 & 0 \\
\hline & $\beta_{1}$ & + & 0 & + \\
\hline & $\beta_{2}$ & + & 0 & + \\
\hline & $\beta_{3}$ & + & + & + \\
\hline & $\beta_{4}$ & + & + & + \\
\hline & $\beta_{5}$ & + & + & + \\
\hline & $\beta_{6}$ & + & + & + \\
\hline \multirow[t]{7}{*}{ Covariance } & $\mathrm{mo}$ & + & + & - \\
\hline & $\mu_{1}$ & - & 0 & - \\
\hline & $\mu_{2}$ & - & - & - \\
\hline & $\mu_{3}$ & - & - & - \\
\hline & $\mu_{4}$ & 0 & 0 & 0 \\
\hline & $\mu_{5}$ & 0 & 0 & 0 \\
\hline & $\mu_{6}$ & 0 & 0 & 0 \\
\hline
\end{tabular}

Notes: (a) case presents residual autocorrelation in both mean equations (LM test); residuals of ARCH-type in the exchange rate equation; standard deviations in parentheses; * and ** denote significance at $5 \%$ and $10 \%$, respectively. 
However, it can be seen from Table 3 that the significance of $\mu_{1}, \beta_{1}$ and $\beta_{2}$ is the only significant difference between both cases. The difference in the signs of $g_{12}$ and $g_{22}$ does not affect the final result because these coefficients are considered under three situations: (i) squared values; (ii) multiplied by each other, (iii) multiplied by coefficients that are statistically equal to zero. The differences in $a_{11}, a_{22}$ and $a_{12}$, in their turn, fall within standard deviation boundaries, thus, they may not be considered to be significant. It is important to notice that for the inflation equation all cases provided the same signals and the same significance (i.e. if statistically equal to or different from zero). Therefore, our results for the response of IPCA to shocks in E are robust.

Table 3 - Estimated Parameters in Variance and Covariance Equations (Monthly data from 1999:01 to 2004:09)

\begin{tabular}{|c|c|c|c|}
\hline$g_{11}$ & -0.1041899 & -0.0513807 & $0.03980506^{*}$ \\
& $(0.1348117)$ & $(0.11993625)$ & $(0.14292026)$ \\
\hline$g_{21}$ & 0.00810385 & 0.01085598 & $-0.00743866^{*}$ \\
& $(0.01683404)$ & $(0.01418979)$ & $(0.0156595)$ \\
\hline$g_{12}$ & $12.52650218^{*}$ & $-13.00132891^{*}$ & $13.12325566^{*}$ \\
& -155.221 .793 & -168.386 .503 & -198.208 .477 \\
\hline$g_{22}$ & $0.41076103^{* *}$ & $-0.43513845^{*}$ & $0.50120845^{*}$ \\
& $(0.23448881)$ & $(0.21248228)$ & $(0.22752382)$ \\
\hline$a_{11}$ & $0.27491257^{*}$ & $0.40438372^{*}$ & $-0.44434782^{*}$ \\
& $(0.12289452)$ & $(0.13130784)$ & $(0.17146475)$ \\
\hline$a_{21}$ & $0.0595035^{*}$ & $0.05305404^{*}$ & $-0.05393149^{*}$ \\
& $(0.0131604)$ & $(0.01178906)$ & $(0.01283429)$ \\
\hline$a_{12}$ & $-3.42461647^{* *}$ & $-5.71185332^{*}$ & 74.208 .698 \\
& -198.123 .913 & -210.969 .805 & -241.134 .849 \\
\hline$a_{22}$ & $-0.46199166^{*}$ & $-0.59176609^{*}$ & $0.78655762^{*}$ \\
& $(0.1406473)$ & $(0.14044079)$ & $(0.16694871)$ \\
\hline$c_{11}$ & -0.00000016 & -0.00000008 & 0.00000006 \\
& $(0.007226)$ & $(0.00455714)$ & $(0.00519676)$ \\
\hline$c_{21}$ & $0.00211834^{*}$ & $0.00175652^{*}$ & $-0.00189984^{*}$ \\
& $(0.00037541)$ & $(0.00033542)$ & $(0.00031271)$ \\
\hline$c_{22}$ & 0.00366595 & 0.0038599 & -0.00462995 \\
& $(0.00836578)$ & $(0.00918004)$ & $(0.01001528)$ \\
& $(0.00836578)$ & $(0.00918004)$ & $(0.01001528)$ \\
\hline
\end{tabular}

The Wald Test was performed to decide between the cases considered. The unrestricted case - that is, case (2) - was preferred to the detriment of cases (1) and (3), as shown in Table 4. Hence, we will consider case (2) as our results from now on.

Tables 5 to 8 show the results of the Ljung-Box and LM tests for auto-correlation of residuals, the Arch-LM test for Arch-type residuals, the multivariate Portmanteau test for cross-correlation and the eigenvalue vector ${ }^{16}$ for case 2 . As it can be seen from these tables, the model estimated in case 2 respects the conditions of no serial autocorrelation or cross-correlation of residuals, no Arch-type residuals and is covariance stationary. Therefore, we can say that the dependence between exchange rate and inflation volatilities was completely captured by the bivariate-Garch model.

By analyzing the results of case 2 , shown in the second column of Table 2 , one can notice that the conditional variance of IPCA is affected (statistically significant) by shocks to the IPCA, E and shocks

\footnotetext{
${ }^{16}$ For a brief explanation of the eingevalue calculation, see Appendix B.
} 
common to both. However, since $\alpha 1$ and $\alpha 3$ are square coefficients, we cannot determine whether the effects of IPCA and E shocks have a positive or negative sign, but we can affirm that they are statistically significant. Lagged variances and covariances, however, do not play a significant role in explaining IPCA variance.

Table 4 - Wald Test ${ }^{a}$

\begin{tabular}{|l|l|l|}
\hline Cases tested & Observed $\chi_{4}^{2}$ statistic & $\begin{array}{l}\text { Null hypothesis: Variables } \\
\text { added in case (2) are not jointly } \\
\text { significant }\end{array}$ \\
\hline Case (1) vs Case (2) & 20.22 & Reject \\
\hline Case (2) vs.Case (3) & 21.30 & Reject \\
\hline
\end{tabular}

${ }^{a}$ Wald Test: $-2(l r-l u) \sim \chi_{q}^{2}$, where $q$ is the number of added variables, $l_{r}$ and $l_{u}$ are the log-likelihood of the restricted and unrestricted cases, respectively. Under $H_{o}$, the added variables are not jointly significant.

Table 5 - Lung-Box Tests for Residual Autocorrelation

\begin{tabular}{|c|c|c|c|c|}
\hline \multirow{2}{*}{ Ljung-Box } & \multicolumn{2}{|c|}{ E1 (residuals of inflation Equation) } & \multicolumn{2}{c|}{ E2 (residuals of exchange rate equation) } \\
\cline { 2 - 5 } & Q-Statistics & Significance Level & Q-Statistics & Significance Level \\
\hline $\mathrm{Q}(1-0)$ & 0.0041 & 0.9491 & 0.0934 & 0.7599 \\
\hline $\mathrm{Q}(2-0)$ & 0.8666 & 0.6484 & 0.1501 & 0.9277 \\
\hline $\mathrm{Q}(3-0)$ & 14.555 & 0.6926 & 0.1737 & 0.9817 \\
\hline $\mathrm{Q}(4-0)$ & 18.807 & 0.7577 & 12.716 & 0.8662 \\
\hline $\mathrm{Q}(5-0)$ & 19.857 & 0.8511 & 17.955 & 0.8766 \\
\hline $\mathrm{Q}(6-0)$ & 32.571 & 0.7760 & 23.153 & 0.8885 \\
\hline $\mathrm{Q}(7-0)$ & 36.674 & 0.8172 & 29.063 & 0.8935 \\
\hline $\mathrm{Q}(8-0)$ & 62.370 & 0.6207 & 62.032 & 0.6245 \\
\hline $\mathrm{Q}(9-0)$ & 65.844 & 0.6803 & 63.149 & 0.7080 \\
\hline $\mathrm{Q}(10-0)$ & 68.781 & 0.7369 & 75.265 & 0.6750 \\
\hline $\mathrm{Q}(11-0)$ & 75.425 & 0.7536 & 122.845 & 0.3426 \\
\hline $\mathrm{Q}(12-0)$ & 138.282 & 0.3118 & 129.173 & 0.3751 \\
\hline
\end{tabular}

As for the conditional variance of $E$, it is affected by its lagged values and by lagged values of the conditional variance of IPCA - the latter goes undetected by almost all tests with unconditional variances - although we also cannot make assertions about the sign. Shocks common to both variables $\left(\epsilon_{1, t-1} \epsilon_{2, t-1}\right)$ and in the covariance have a positive and significant sign. Graph 10 shows the estimated conditional variances over time.

Finally, results show us that shocks in the exchange rate (E) and shocks common to exchange rate and IPCA have negative and significant effects over the covariance between the two variables. This is an important result in our model. It means that shocks that affect the exchange rate or the exchange rate and IPCA simultaneously will cause a "disconnection" of these two variables. After all, everything else the same, a reduction in the covariance means a reduction in the correlation coefficient between the variables.

At first, we considered that the lack of convergence for specifications other than the BEKK model would result from the small size of our sample (January, 1999 to September, 2004). However, this may be questioned since the BEKK specification has more parameters than some of the other specifications tested. The negative sign of shocks in $\mathrm{E}$ over the conditional covariance $\left(\mu_{1}<0\right)$ and the dispersion graphs presented below (graphs 11 to 14) suggest that the sign of shocks in E over the conditional 
Table 6 - LM and ARCH-LM Tests

\begin{tabular}{|c|c|c|c|c|c|}
\hline \multirow{2}{*}{ Lags } & Qui-square critical level & \multicolumn{4}{|c|}{$\mathrm{N}^{*} \mathrm{R} 2$ values } \\
\cline { 3 - 6 } & & \multicolumn{2}{|c|}{ Inflation Equation } & \multicolumn{2}{|c|}{ Exchange Rate Equation } \\
\hline & at 5\% & LM test & Arch-LM test & LM test & Arch-LM test \\
1 & 38.415 & 11.927 & 0.9080 & 33.525 & 0.4656 \\
\hline 2 & 59.915 & 49.930 & 21.524 & 41.045 & 30.632 \\
\hline 3 & 78.147 & 55.838 & 65.384 & 27.580 & 33.708 \\
\hline 4 & 94.877 & 62.760 & 78.664 & 53.360 & 36.771 \\
\hline 5 & 110.705 & 78.937 & 80.904 & 72.583 & 34.554 \\
\hline 6 & 125.916 & 85.463 & 89.747 & 93.236 & 42.765 \\
\hline 7 & 140.671 & 121.124 & 89.349 & 130.569 & 47.729 \\
\hline 8 & 155.073 & 146.820 & 91.488 & 185.930 & 49.308 \\
\hline 9 & 169.190 & 149.107 & 95.050 & 181.027 & 54.148 \\
\hline 10 & 183.070 & 148.134 & 99.457 & 183.225 & 53.254 \\
\hline 11 & 196.751 & 151.475 & 113.772 & 207.173 & 57.317 \\
\hline 12 & 210.261 & 197.229 & 97.259 & 202.341 & 100.397 \\
\hline
\end{tabular}

${ }^{a}$ The $\mathrm{N}^{*} \mathrm{R} 2$ value must be $<$ than the 2 to accept the null hypotheses of no autocorrelation and arch residuals

Table 7 - Multivariate Portmanteau Test for Cross-Correlation ${ }^{a}$

\begin{tabular}{|c|c|c|}
\hline $\mathrm{M}$ & Test Statistics & Significance Level \\
\hline 3 & 56.954 & 0.3370 \\
\hline 5 & 122.948 & 0.5036 \\
\hline 7 & 165.348 & 0.7389 \\
\hline 10 & 250.132 & 0.8394 \\
\hline 12 & 362.776 & 0.6803 \\
\hline 15 & 452.643 & 0.7660 \\
\hline
\end{tabular}

${ }^{a} H_{0}: \rho_{1}=\rho_{2}=\cdots=\rho_{m}=0$ and $H_{a}: \rho_{i} \neq 0$ for some $i \in\{1, \ldots, m\}$ (See Tsay (2002), for the multivariate Portmanteau test for cross-correlation).

Table 8 - Eigenvalue Vector

$\mathrm{Y}=\mid \begin{gathered}0.6630 \\ -0.4252 \\ -0.0770 \\ 0.0637\end{gathered}$


Figure 10 - Conditional Variances - IPCA and E

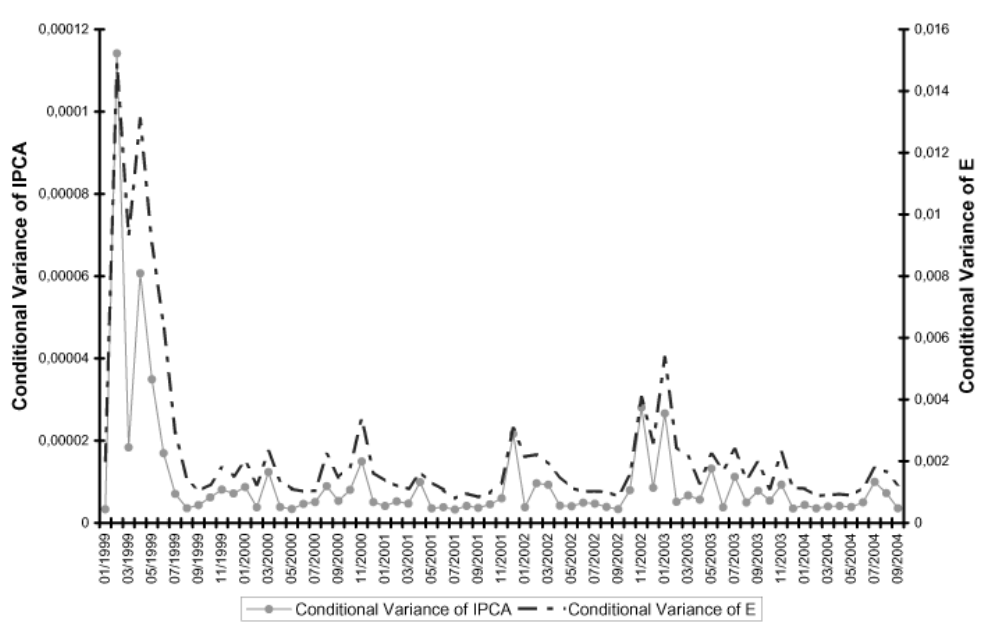

variance of IPCA may not be the same all the time. If this is true, then we may have a reason for the non-convergence of specifications that, instead of working with squared terms (imposing the positivity of the matrix), try to find a sign for the relation. In these specifications, if the signs of a coefficient in the equations of exchange rate's and inflation's variances change from positive to negative, they will not converge to a final value, since the model will have to establish whether the coefficient is positive or negative. In the BEKK specification, however, this problem does not exist once it works with square coefficients. However, further tests are necessary before we can make such assertion.

Graphs 11 to 14 are dispersion graphs with the conditional variances of $\mathrm{E}$ on the horizontal axis and of IPCA on the vertical axis. Graph 11 plots the entire sample and one can clearly see four outliers in that graph, which correspond to the period between February and May 1999 (i.e. the first months after the change in the exchange rate regime, caused by the 1999 crisis, and before the adoption of the inflationtargeting regime in June of that year). Hence, we excluded these observations and built Graph 12 . Again, five outliers were removed to construct Graph 13 (June 1999, November 2000, December 2001, December 2002 and January 2003). Graph 14, in its turn, was built using only the region with the highest concentration of observations ( $57 \%$ of the sample). ${ }^{17}$

Graph 12 and, mainly, graph 13 suggest a semiconcave (if not concave) relation between the two variables at stake (i.e. the conditional variances of exchange rate and of IPCA). To illustrate the relation, a trend was included in those graphs and in graph 14, and the adjusted $R^{2}$ of each trend equation was reported (see graphs 15 to 17 in the appendix A). The semiconcave relation would imply that, although the response of inflation volatility to exchange rate volatility is positive, the proportion in its variation decreases as exchange rate volatility rises.

If we consider graph 14, which plots the region with the highest concentration of observations, we find a clear concave relation. This would mean that, after a certain point, the positive relation between volatilities becomes negative, as opposed to the convex form observed in financial variables (the socalled smile of volatility). Also, it is possible that it is reflecting the existence of a regime switching in the volatilities, since we are removing the extreme values of the sample. We need a longer sample to

\footnotetext{
${ }^{17}$ The observations removed from Graph 14 are, related to Graph 11: January to July 1999; November 1999 to January 2000; March, August, October and November 2000; April 2001; December 2001 to March 2002; October 2002 to March 2003; May, July, September and November 2003 and August 2004.
} 
test if this behavior would be reproduced over time. However, we can only use graph 14 to speculate about these possibilities happening. Nonetheless, it is a question to be answered in future research, since some works of other authors find, as we pointed out in the introduction, the sign may change according to the model's parameters.

Figure 11 - Exchange rate and inflation volatilities (full sample)

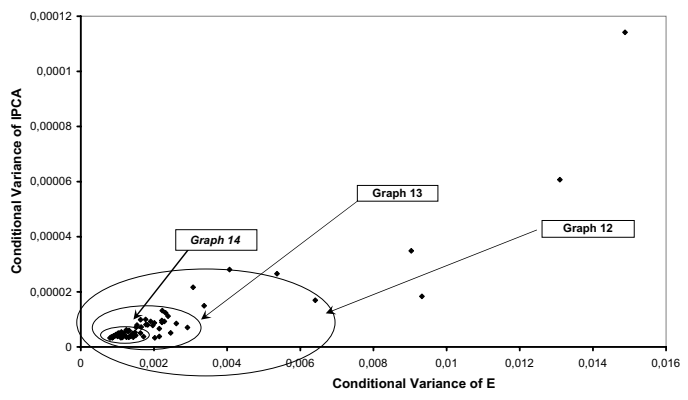

Figure 13 - Exchange rate and inflation volatilities (reduced sample)

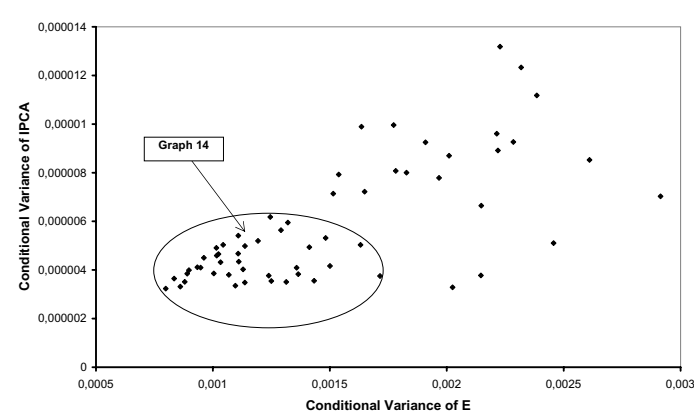

Figure 12 - Exchange rate and inflation volatilities (reduced sample)

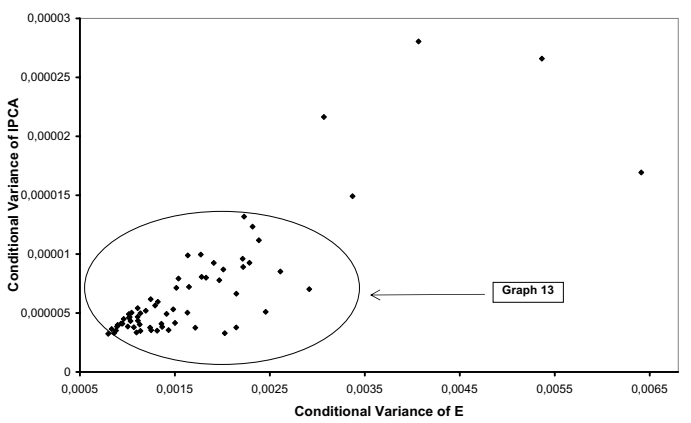

Figure 14 - Exchange rate and inflation volatilities (reduced sample)

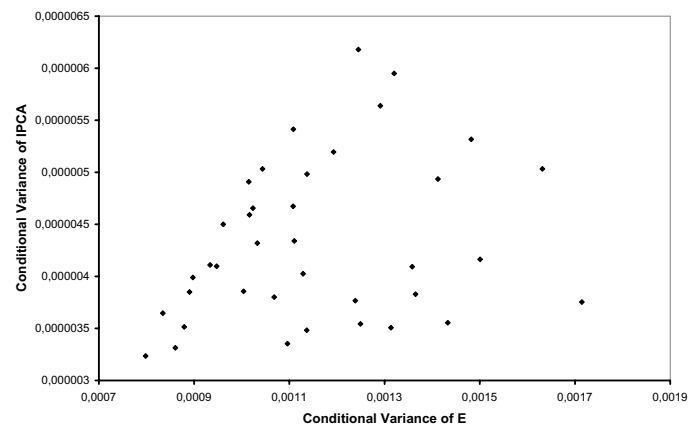

\section{CONCLUSIONS}

The analysis presented in sections IV and V show that the use of unconditional variances leads us to results that are sensitive to the chosen measure of volatility, which is based on subjective criteria. The multivariate GARCH model, dealing directly with the effects of conditional volatilities, finds a semiconcave relation (differently from the case for financial series, where this relation has a convex form), statistically significant, between exchange rate and inflation variances.

The results seem to be in line with the intuition obtained from other studies, especially Dixit (1989) and Seabra (1996). When exchange rate volatility is very high, increasing uncertainty, inflation response may be reduced, leading to smaller effects. This may explain why some studies to placecountryregionBrazil found a decrease in the short-run pass-through from exchange rates to consumer prices after the floating regime.

The analysis based on the role played by uncertainty could also make a bridge between the two different points of view concerning the existence of a relation between the volatilities of exchange 
rate and inflation. The relation would exist but, under certain conditions, the disconnection between the variables would be too strong to be noticed. In periods of high volatility, agents will not respond with the same intensity as they do in periods of stability due to the lack of knowledge concerning the duration of the movements in the exchange rate (whether temporary or permanent). Therefore, inflation volatility has smaller amplitude. On the other hand, when exchange rate volatility is lower, inflation would answer more promptly. ${ }^{18}$ This disconnection becomes clearer in the negative sign found in the answer of the conditional covariance to shocks in the exchange rate and would be reinforced if the sign reversion found in graph 14 is verified in future studies.

The caveats of this paper basically lie in the small sample available for placecountry-regionBrazil, since the floating regime for exchange rates having started only in 1999. Because of that, we cannot establish with certainty whether the problems faced with convergence were due to the sign instability or to the small period involved. Nonetheless, we tend not to rely too much in the small sample explanation, since three out of the other four restrictions tested - diagonal VEC, CCORR and DCC - have less parameters to be estimated. Nonetheless, a large sample is essential to corroborate the results.

However, this article innovates by (i) applying a multivariate GARCH model, thus, considering conditional variances to analyze the relation between volatilities, (ii) trying to establish a relation between exchange rate and inflation volatilities and its possible implications for monetary policy and (iii) showing that traditional tests performed with exogenously constructed volatility series are sensitive to the criteria chosen to construct such series and do not reveal relevant features of that relation.

\section{Bibliography}

Andersen, T. M. (1997). Exchange rate volatility, nominal rigidities, and persistent deviations from ppp. Journal of the Japanese and International Economies, 11(4):584-609. available at http: //ideas . repec.org/a/eee/jjieco/v11y1997i4p584-609.html.

Barkoulas, J. T., Baum, C. F., \& Caglayan, M. (2002). Exchange rate effects on the volume and variability of trade flows. Journal of International Money and Finance, 21(4):481-496. available at http://ideas . repec. org/a/eee/jimf in/v21y2002i4p481-496.html.

Barone-Adesi, G. \& Yeung, B. (1990). Price flexibility and output volatility: the case for flexible exchange rate. Journal of International Money and Finance, 9:276-298.

Barro, R. J. \& Gordon, D. B. (1983). Rules, discretion and reputation in a model of monetary policy. Journal of Monetary Economics, 12(1):101-121. available at http://ideas.repec.org/a/eee/moneco/ v12y1983i1p101-121.html.

Baxter, M. \& Stockman, A. (1988). Business cycle and the exchange rate system: some international evidence. NBER Working Papers 2689, National Bureau of Economic Research, Inc.

Bleaney, M. \& Fielding, D. (2002). Exchange rate regimes, inflation and output volatility in developing countries. Journal of Development Economics, 68(1):233-245. available at http://ideas.repec. org/a/eee/deveco/v68y2002i1p233-245.html.

Bleaney, M. F. (1996). Macroeconomic stability, investment and growth in developing countries. Journal of Development Economics, 48(2):461-477. available at http: //ideas .repec .org/a/eee/deveco/ v48y1996i2p461-477.html.

\footnotetext{
${ }^{18}$ For instance, in an environment with fixed exchange rates, the agents know that devaluation is permanent. Therefore, facing a new level of the exchange rates, they need to adjust their costs. The same is not true under a floating system: agents have costs to adjust their prices to a new level of exchange rates and costs to return to the original position if the (de)valuation is not permanent.
} 
Bollerslev, T. (1990). Modelling the coherence in short-run nominal exchange rates: A multivariate generalized arch model. The Review of Economics and Statistics, 72(3):498-505. available at http: //ideas.repec.org/a/tpr/restat/v72y1990i3p498-505.html.

Bollerslev, T., Engle, R. F., \& Wooldridge, J. M. (1988). A capital asset pricing model with time-varying covariances. Journal of Political Economy, 96(1):116-31. available at http://ideas.repec .org/a/ ucp/jpolec/v96y1988i1p116-31.html.

Calvo, G. A. \& Reinhart, C. M. (2000a). Fear of floating. NBER Working Papers 7993, National Bureau of Economic Research, Inc. available at http://ideas.repec.org/p/nbr/nberwo/7993.html.

Calvo, G. A. \& Reinhart, C. M. (2000b). Fixing for your life. NBER Working Papers 8006, National Bureau of Economic Research, Inc. available at http: //ideas.repec.org/p/nbr/nberwo/8006.html.

Carrera, J. \& Bastourre, D. (2004). Could the exchange rate regime reduce macroeconomic volatility? In Econometric Society 2004: Latin American Meetings (LAMES). Econometric Society. available at http: //ideas.repec.org/p/ecm/latm04/309.html.

Chen, N. (2004). The behaviour of relative prices in the european union: A sectoral analysis. European Economic Review, 48:1257-1286.

Devereux, M. B. \& Engel, C. (2003). Monetary policy in the open economy revisited: Price setting and exchange-rate flexibility. Review of Economic Studies, 70(4):765-783. available at http://ideas . repec.org/a/bla/restud/v70y2003i4p765-783.html.

Dixit, A. K. (1989). Hysteresis, import penetration, and exchange rate pass-through. The Quarterly Journal of Economics, 104(2):205-28. available at http://ideas.repec.org/a/tpr/qjecon/ v104y1989i2p205-28.html.

Duarte, M. \& Stockman, A. (2002). Comment on: Exchange rate pass-through, exchange rate volatility, and exchange rate disconnect. Journal of Monetary Economics, 49(5):941-946.

Enders, W. (1995). Applied econometric time serie. John Wiley \& Sons, Nova York.

Engel, C. \& Rogers, J. H. (2001). Deviations from purchasing power parity: causes and welfare costs. Journal of International Economics, 55(1):29-57. available at http://ideas.repec.org/a/eee/ inecon/v55y2001i1p29-57.html.

Engle, R. (2002). Dynamic conditional correlation: A simple class of multivariate generalized autoregressive conditional heteroskedasticity models. Journal of Business \& Economic Statistics, 20(3):339-50. available at http://ideas.repec.org/a/bes/jnlbes/v20y2002i3p339-50.html.

Engle, R. F. \& Kroner, K. F. (1993). Multivariate simultaneous generalized arch. Economics Working Paper Series 89-57r, Department of Economics, University of California at San Diego. available at http://ideas.repec.org/p/cdl/ucsdec/89-57r.html.

Flood, R. P. \& Rose, A. K. (1995). Fixing exchange rates a virtual quest for fundamentals. Journal of Monetary Economics, 36(1):3-37. available at http://ideas.repec.org/a/eee/moneco/ v36y1995i1p3-37.html.

Ghosh, A. R., Gulde, A.-M., Ostry, J. D., \& Wolf, H. C. (1997). Does the nominal exchange rate regime matter? NBER Working Papers 5874, National Bureau of Economic Research, Inc. available at http: //ideas.repec.org/p/nbr/nberwo/5874.html. 
Hausmann, R., Panizza, U., \& Stein, E. (2001). Why do countries float the way they float? Journal of Development Economics, 66(2):387-414. available at http://ideas.repec.org/a/eee/deveco/ v66y2001i2p387-414.html.

Krugman, P. (1988). Exchange Rate Instability. The MIT press, Cambridge, MA.

Obstfeld, M. \& Rogoff, K. (2000). The six major puzzles in international macroeconomics: Is there a common cause? NBER Working Papers 7777, National Bureau of Economic Research, Inc. available at http://ideas.repec.org/p/nbr/nberwo/7777.html.

Rogoff, K. (2001). Perspectives on exchange rate volatility. In Feldstein, M., editor, International Capital Flows, pages 441-453. University of Chicago Press.

Seabra, F. (1996). A relação teórica entre incerteza cambial e investimento: os modelos neoclássico e de investimento irreversível. Política e Planejamento Econômico, 26(2):183-202.

Smith, C. E. (1999). Exchange rate variation, commodity price variation and the implications for international trade. Journal of International Money and Finance, 18(3):471-491. available at http://ideas.repec.org/a/eee/jimfin/v18y1999i3p471-491.html.

Sutherland, A. (2005). Incomplete pass-through and the welfare effects of exchange rate variability. Journal of International Economics, 65(2):375-399. available at http://ideas.repec.org/a/eee/inecon/v65y2005i2p375-399.html.

Tsay, R. S. (2002). Analysis of Financial Time Series. John Wiley \& Sons, Inc.

Wei, S.-J. \& Parsley, D. C. (1995). Purchasing power disparity during the floating rate period: Exchange rate volatility, trade barriers and other culprits. NBER Working Papers 5032, National Bureau of Economic Research, Inc. available at http://ideas.repec.org/p/nbr/nberwo/5032.html.

\section{A. TABLES \& GRAPHS}

Table 9 - ADF Unit Root Test

\begin{tabular}{|l|l|l|l|l|}
\hline \multicolumn{5}{|c|}{ sample: 2000:03 to 2004:10 } \\
\hline Variable & $\begin{array}{l}\text { ADF test statis- } \\
\text { tics } \\
\text { Critical value at } \\
5 \%\end{array}$ & $\begin{array}{l}\text { ADF test statis- } \\
\text { tics - first differ- } \\
\text { ence of the vari- } \\
\text { able }\end{array}$ & $\begin{array}{l}\text { Critical value at } \\
5 \%\end{array}$ \\
\hline Price Index & $-2.1704(\mathrm{a})$ & -34.783 & $-3.904127(\mathrm{a})$ & -34.783 \\
\hline Exchange Rate & $-1.7097(\mathrm{a})$ & -34.783 & $-7.427513(\mathrm{a})$ & -34.783 \\
\hline External Prices & $-1.5419(\mathrm{a})$ & -34.783 & $-8.014687(\mathrm{a})$ & -34.793 \\
\hline GAP & -97.018 & -29.077 & - & - \\
\hline
\end{tabular}

Note: test performed with (a) trend or intercept and (b) without trend. 
Table 10 - ADF Unit Root Test - std. dev.

\begin{tabular}{|l|l|l|l|l|}
\hline \multicolumn{5}{|c|}{ sample: 2000:03 to 2004:10 } \\
\hline Variable & $\begin{array}{l}\text { ADF test statis- } \\
\text { tics }\end{array}$ & $\begin{array}{l}\text { Critical Value at } \\
5 \%\end{array}$ & $\begin{array}{l}\text { ADF test statis- } \\
\text { tics first differ- } \\
\text { ence of variables }\end{array}$ & $\begin{array}{l}\text { Critical Value at } \\
5 \%\end{array}$ \\
\hline IPCA_4 & -34.697 & -34.805 & - & - \\
\hline IPCA_6 & $-1.8540(a)$ & -19.461 & - & - \\
\hline IPCA_8 & -1.3046 (a) & -19.463 & -70.015 & -34.865 \\
\hline IPCA_12 & $-0.8823(a)$ & -19.465 & -59.875 & -34.921 \\
\hline E_4 & -119.597 & -34.816 & - & - \\
\hline E_6 & $-10.8574(\mathrm{~b})$ & -29.084 & - & - \\
\hline E_8 & $-9.5054(\mathrm{~b})$ & -29.100 & - & - \\
\hline E_12 & $-7.5521(\mathrm{~b})$ & -29.136 & - & - \\
\hline
\end{tabular}

Note: test performed with (a) trend or intercept and (b) without trend.

Table 11 - VAR for four-month windows

\begin{tabular}{|c|c|c|c|c|c|}
\hline Variables & E_4 & IPCA_4 & Variables & E_4 & IPCA_4 \\
\hline E_4(-1) & 0.2790 & $-5.65 \mathrm{E}-05$ & D2002_M11 & 0.005 & $7.11 \mathrm{E}-05$ \\
& $(0.0449)$ & $(0.0004)$ & & $(0.001)$ & $(8.7 \mathrm{E}-06)$ \\
& {$[6.2085]$} & {$[-0.1423]$} & & {$[5.1319]$} & {$[8.1232]$} \\
\hline IPCA_4(-1) & 21.8600 & 0.7206 & D1999 & 0.0121 & $1.59 \mathrm{E}-06$ \\
& $(7.7321)$ & $(0.0683)$ & & $(0.0015)$ & $(1.4 \mathrm{E}-05)$ \\
& {$[2.8272]$} & {$[10.5446]$} & & {$[7.8898]$} & {$[0.1177]$} \\
\hline C & 0.0004 & $2.27 \mathrm{E}-06$ & R-squared & 0.8856 & 0.7384 \\
& $(0.0002)$ & $(1.4 \mathrm{E}-06)$ & Adj. R-squared & 0.8779 & 0.7210 \\
& {$[2.2992]$} & {$[1.5965]$} & F-statistic & 116.0581 & 42.3377 \\
\hline
\end{tabular}

Note: standard deviations between parenthesis; t-statistics in brackets. 
Table 12 - VAR for six-month windows

\begin{tabular}{|l|l|l|l|l|l|l|l|l|}
\hline Variables & E_6 & IPCA_6 & Variables & E_6 & IPCA_6 & Variables & E_6 & IPCA_6 \\
\hline E_6(-1) & 0.9027 & 0.0034 & E_6(-6) & 0.0706 & -0.0010 & IPCA_6(-5) & -265.070 & -0.0059 \\
& $(0.1118)$ & $(0.0018)$ & & $(0.0482)$ & $(0.0008)$ & & $(7.8289)$ & $(0.1248)$ \\
& {$[8.0747]$} & {$[1.9157]$} & & {$[1.4657]$} & {$[-1.343]$} & & {$[-3.3858]$} & {$[-0.0469]$} \\
\hline E_6(-2) & 0.0398 & -0.0064 & IPCA_6(-1) & 0.4882 & 0.8246 & IPCA_6(-6) & 19.6540 & -0.0141 \\
& $(0.1483)$ & $(0.0024)$ & & $(7.085)$ & $(0.1129)$ & & $(6.1560)$ & $(0.0981)$ \\
& {$[0.2684]$} & {$[-2.7097]$} & & {$[0.0689]$} & {$[7.3032]$} & & {$[3.1927]$} & {$[-0.1434]$} \\
\hline E_6(-3) & 0.0239 & -0.0002 & IPCA_6(-2) & 1.8361 & 0.1457 & C & 0.0002 & $1.86 \mathrm{E}-06$ \\
& $(0.1548)$ & $(0.0025)$ & & $(9.0902$ & $(0.1449)$ & & $(0.0001)$ & $(1.8 \mathrm{E}-$ \\
& & & & & & & & $06)$ \\
& {$[0.1546]$} & {$[-0.0727]$} & & {$[0.202]$} & {$[1.0061]$} & & {$[1.8206]$} & {$[1.0462$} \\
\hline E_6(-4) & -0.1345 & 0.0043 & IPCA_6(-3) & -43.719 & -0.0721 & D2002_M11 & 0.0028 & $4.59 \mathrm{E}-05$ \\
& $(0.1139)$ & $(0.0018)$ & & $(8.7652)$ & $(0.1397)$ & & $(0.0004)$ & $(6.8 \mathrm{E}-$ \\
& & & & & & & & \\
& {$[-1.1809]$} & {$[2.3814]$} & & {$[-0.4989]$} & {$[-0.5159]$} & & {$[6.5062]$} & {$[6.7698]$} \\
\hline E_6(-5) & -0.1018 & 0.0005 & IPCA_6(-4) & 7.9487 & -0.0954 & R-squared & 0.88102 & 0.8588 \\
& $(0.0874)$ & $(0.0019)$ & & $(8.6463)$ & $(0.1378)$ & F-statistic & 25.0626 & 20.5897 \\
& {$[-1.1643]$} & {$[0.3891]$} & & {$[0.9193]$} & {$[-0.6920]$} & Adj. r R- & 0.8459 & 0.8171 \\
& & & & & & squared & & \\
\hline
\end{tabular}

Table 13 - VAR for eight-month windows

\begin{tabular}{|c|c|c|c|c|c|}
\hline Variables & E_8 & D_IPCA_8 & Variables & E_8 & D_IPCA_8 \\
\hline E_8(-1) & 0.7930 & 0.0016 & D_IPCA_8(-2) & 53.804 & -0.04323 \\
& $(0.0987)$ & $(0.001)$ & & -91.884 & $(0.0900)$ \\
& {$[8.0398]$} & {$[1.6026]$} & & {$[0.5856]$} & {$[-0.4790]$} \\
\hline E_8(-2) & 0.0097 & -0.0006 & C & 0.0002 & $-1.79 \mathrm{E}-06$ \\
& $(0.0674)$ & $(0.0007)$ & & $(0.0001)$ & $(1.1 \mathrm{E}-06)$ \\
& {$[0.1439]$} & {$[-0.9426]$} & & {$[1.8207]$} & {$[-1.63756]$} \\
\hline D_IPCA_8(-1) & 18.755 & 0.09867 & D2002_M11 & 0.0015 & $4.21 \mathrm{E}-05$ \\
& -9.215 & $(0.0903)$ & & $(0.0005)$ & $(5.2 \mathrm{E}-06)$ \\
& $0.2035]$ & {$[1.0922]$} & & {$[2.8223]$} & {$[8.1145]$} \\
R-squared & 0.721 & 0.5781 & Adj. R-squared & 0.6947 & 0.5383 \\
F-statistic & 273.886 & 145.247 & & & \\
\hline
\end{tabular}


Table 14 - VAR for twelve-month windows

\begin{tabular}{|c|c|c|c|c|c|c|c|c|}
\hline Variables & E_12 & D_IPCA_12 & Variables & E_12 & D_IPCA_12 & Variables & E_12 & D_IPCA_12 \\
\hline E_12(-1) & $\begin{array}{l}11.266 \\
(0.1548) \\
{[7.2795]}\end{array}$ & $\begin{array}{l}0.0066 \\
(0.0017) \\
{[3.9409]}\end{array}$ & E_12(-7) & $\begin{array}{l}-0.01345 \\
(0.0727) \\
{[-0.1849]}\end{array}$ & $\begin{array}{l}0.00166 \\
(0.0008) \\
{[2.1149]}\end{array}$ & D_IPCA_12(-6) & $\begin{array}{l}695.244 \\
-81.141 \\
{[0.8568]}\end{array}$ & $\begin{array}{l}-0.0856 \\
(0.0874) \\
{[-0.9788]}\end{array}$ \\
\hline E_12(-2) & $\begin{array}{l}-0.0864 \\
(0.2702) \\
{[-0.3197]}\end{array}$ & $\begin{array}{l}-0.0041 \\
(0.0029) \\
{[-1.394]}\end{array}$ & D_IPCA_12(-1) & $\begin{array}{l}-73.151 \\
-99.846 \\
{[-0.7326]}\end{array}$ & $\begin{array}{l}0.1543 \\
(0.1076) \\
{[1.4338]}\end{array}$ & D_IPCA_12(-7) & $\begin{array}{l}-81.538 \\
-76.083 \\
{[-1.0717]}\end{array}$ & $\begin{array}{l}0.0164 \\
(0.082) \\
{[0.2005]}\end{array}$ \\
\hline E_12(-3) & $\begin{array}{l}-0.15121 \\
(0.2749) \\
{[-0.5499]}\end{array}$ & $\begin{array}{l}0.0009 \\
(0.003) \\
{[0.3009]}\end{array}$ & D_IPCA_12(-2) & $\begin{array}{l}53.827 \\
-98.458 \\
{[0.5467]}\end{array}$ & $\begin{array}{l}0.107 \\
(0.1061) \\
{[1.0081]}\end{array}$ & C & $\begin{array}{l}8.75 \mathrm{E}-05 \\
(9.6 \mathrm{E}-05) \\
{[0.9099]}\end{array}$ & $\begin{array}{l}-1.55 \mathrm{E}-06 \\
(1.0 \mathrm{E}-06) \\
{[-1.4988]}\end{array}$ \\
\hline E_12(-4) & $\begin{array}{l}0.1970 \\
(0.2605) \\
{[0.7565]}\end{array}$ & $\begin{array}{l}-0.0028 \\
(0.0028) \\
{[-0.9924]}\end{array}$ & D_IPCA_12(-3) & $\begin{array}{l}-118.497 \\
-105.016 \\
{[-1.12837]}\end{array}$ & $\begin{array}{l}-0.0342 \\
(0.1132) \\
{[-0.3018]}\end{array}$ & D2002_M11 & $\begin{array}{l}-0.000391 \\
(0.0003) \\
{[-1.1375]}\end{array}$ & $\begin{array}{l}2.64 \mathrm{E}-05 \\
(3.7 \mathrm{E}-06) \\
{[7.1275]}\end{array}$ \\
\hline E_12(-5) & $\begin{array}{l}-0.1114 \\
(0.2391) \\
{[-0.466]}\end{array}$ & $\begin{array}{l}0.0021 \\
(0.0026) \\
{[0.7939]}\end{array}$ & D_IPCA_12(-4) & $\begin{array}{l}-0.5193 \\
-101.884 \\
{[-0.051]}\end{array}$ & $\begin{array}{l}-0.1149 \\
(0.1098) \\
{[-1.0465]}\end{array}$ & D2003_M10 & $\begin{array}{l}-0.0018 \\
(0.0004) \\
{[-5.0760]}\end{array}$ & $\begin{array}{l}1.46 \mathrm{E}-05 \\
(3.8 \mathrm{E}-06) \\
{[3.8268]}\end{array}$ \\
\hline E_12(-6) & $\begin{array}{l}0.0218 \\
(0.1654) \\
{[0.1315]}\end{array}$ & $\begin{array}{l}-0.0040 \\
(0.0018) \\
{[-2.2462]}\end{array}$ & D_IPCA_12(-5) & $\begin{array}{l}142.164 \\
-92.135 \\
{[1.543]}\end{array}$ & $\begin{array}{l}0.0848 \\
(0.0993) \\
{[0.8540]}\end{array}$ & $\begin{array}{l}\text { R-squared } \\
\text { Adj. R-squared } \\
\text { F-statistic }\end{array}$ & $\begin{array}{l}0.9317 \\
0.8986 \\
281.265\end{array}$ & $\begin{array}{l}0.8543 \\
0.7837 \\
120.931\end{array}$ \\
\hline
\end{tabular}

Table 15 - ADF Unit Root Test - variances

\begin{tabular}{|l|l|l|l|l|}
\hline \multicolumn{5}{|c|}{ sample: 2000:03 to 2004:10 } \\
\hline Variable & $\begin{array}{l}\text { ADF test statis- } \\
\text { tics }\end{array}$ & $\begin{array}{l}\text { Critical Value at } \\
5 \%\end{array}$ & $\begin{array}{l}\text { ADF test statis- } \\
\text { tics first differ- } \\
\text { ence of variables }\end{array}$ & $\begin{array}{l}\text { Critical Value at } \\
5 \%\end{array}$ \\
\hline p4 & $-3.2566(\mathrm{~b})$ & -29.069 & - & - \\
\hline p6 & $-2.5156(\mathrm{~b})$ & -29.084 & -73.599 & -3.484 \\
\hline p8 & $-0.8460(\mathrm{a})$ & -19.463 & -73.398 & -34.865 \\
\hline p12 & $-0.4167(\mathrm{a})$ & -19.467 & -59.193 & -34.922 \\
\hline e4 & -65.715 & -34.816 & - & - \\
\hline e6 & $-5.8641(\mathrm{~b})$ & -29.084 & - & - \\
\hline e8 & $-5.4361(\mathrm{~b})$ & -29.100 & - & - \\
\hline e12 & $-4.5351(\mathrm{~b})$ & -29.136 & - & - \\
\hline
\end{tabular}

Note: test performed with (a) trend or intercept and (b) without trend

Table 16 - VAR for four-month windows

\begin{tabular}{|c|c|c|c|c|c|}
\hline Variable & $\mathrm{E} 4$ & $\mathrm{p} 4$ & Variables & $\mathrm{E} 4$ & $\mathrm{p} 4$ \\
\hline E4(-1) & 0.6525 & 0.002503 & $\mathrm{C}$ & 0.0088 & 0.0008 \\
& $(0.0605)$ & $(0.00665)$ & & $(0.0032)$ & $(0.0004)$ \\
& {$[10.7898]$} & {$[0.37628]$} & & {$[2.7471]$} & {$[2.1113]$} \\
\hline P4(-1) & 0.0791 & 0.700972 & R-squared & 0.6643 & 0.4998 \\
& $(0.8394)$ & $(0.09233)$ & Adj. R-squared & 0.6534 & 0.4837 \\
& {$[0.0942]$} & {$[7.59224]$} & F-statistic & 613.330 & 30.976 \\
\hline
\end{tabular}

Note: Std. deviations in parentheses and t-statistics in square brackets. 


\section{rbe}

Testing nonlinearities between Brazilian exchange rate and inflation volatilities

Table 17 - VAR for six-month windows

\begin{tabular}{|c|c|c|c|c|c|}
\hline Variable & E6 & dp6 & Variable & E6 & dp6 \\
\hline e6(-1) & 0.7630 & 0.0083 & Dp6(-1) & 0.7124 & 0.0221 \\
& $(0.1127)$ & $(0.0136)$ & & $(0.8625)$ & $(0.1044)$ \\
& {$[6.7736]$} & {$[0.6068]$} & & {$[0.826]$} & {$[0.2116]$} \\
\hline e6(-2) & 0.0101 & -0.0126 & Dp6(-2) & 0.43334 & -0.1202 \\
& $(0.0903)$ & $(0.0109)$ & & $(0.8515)$ & $(0.1031)$ \\
& {$[0.1113]$} & {$[-1.1549]$} & & {$[0.509]$} & {$[-1.1664]$} \\
\hline C & 0.0064 & $3.82 \mathrm{E}-05$ & D2002_M11 & 0.02998 & 0.0056 \\
& $(0.0024)$ & $(0.0003)$ & & $(0.0077)$ & $(0.0009)$ \\
& {$[2.6605]$} & {$[0.1319]$} & & {$[3.8767]$} & {$[6.0109]$} \\
\hline R-squared & 0.7255 & 0.4332 & Adj. R-squared & 0.7006 & 0.3817 \\
F-statistic & 290.747 & 84.069 & & & \\
\hline
\end{tabular}

Table 18 - VAR for eight-month windows

\begin{tabular}{|c|c|c|c|c|c|}
\hline Variable & E8 & dp8 & Variables & E8 & dp8 \\
\hline e8(-1) & 0.8994 & 0.0203 & dp8(-1) & 0.0669 & 0.0222 \\
& $(0.1177)$ & $(0.0151)$ & & -10.564 & $(0.1351)$ \\
& {$[7.6418]$} & {$[1.3501]$} & & {$[0.0633]$} & {$[0.1639]$} \\
\hline e8(-2) & -0.0595 & -0.0136 & dp8(-2) & 0.1905 & -0.007 \\
& $(0.0988)$ & $(0.0126)$ & & -10.548 & $(0.1349)$ \\
& {$[-0.6021]$} & {$[-1.0740]$} & & {$[0.1806]$} & {$[-0.0512]$} \\
\hline C & 0.0052 & -0.0002 & R-squared & 0.7267 & 0.0338 \\
& $(0.0025)$ & $(0.0003)$ & Adj. R-squared & 0.7064 & -0.0378 \\
& {$[2.0663]$} & {$[-0.6696]$} & F-statistic & 358.896 & 0.4722 \\
\hline
\end{tabular}

Table 19 - VAR for twelve-month windows

\begin{tabular}{|l|l|l|l|l|l|l|l|l|}
\hline Variables & E12 & dp12 & Variables & E12 & dp12 & Variables & E12 & dp12 \\
\hline e12(-1) & 0.9752 & 0.0413 & dp12(-1) & -0.9046 & 0.1774 & C & 0.0028 & -0.0004 \\
& $(0.1086)$ & $(0.0124)$ & & -11.596 & $(0.1325)$ & & $(0.0023)$ & $(0.0003)$ \\
& {$[8.976]$} & {$[3.3225]$} & & {$[-0.7802]$} & {$[1.3391]$} & & {$[1.2268]$} & {$[-1.5782]$} \\
\hline e12(-2) & -0.0543 & -0.0290 & dp12(-2) & -0.1943 & 0.17707 & $\begin{array}{l}\text { R- } \\
\text { squared } \\
\text { Adj. R- } \\
\text { squared }\end{array}$ & 0.8348 & 0.245 \\
& $(0.1014)$ & $(0.0116)$ & & -11.187 & 0.8216 & 0.1846 \\
& & & & $(0.1278)$ & F- \\
& {$[-0.5357]$} & {$[-2.5057]$} & & {$[-0.1736]$} & {$[1.3851]$} & 631.833 & 40.552 \\
\hline
\end{tabular}


Table 20 - Cointegration test between exchange rate and consumer price index

\begin{tabular}{|c|c|c|c|c|c|}
\hline \multicolumn{6}{|c|}{ Trend assumption: Linear deterministic trend } \\
\hline \multicolumn{6}{|c|}{ Series: $\ln$ (exchange rates) and ln (consumer price index); Lag interval (in first differences): 1 to 4} \\
\hline \multicolumn{6}{|c|}{ Unrestricted Cointegration Rank Test (Trace) } \\
\hline $\begin{array}{l}\text { Number of coin- } \\
\text { tegration vectors } \\
\text { under } H_{0}\end{array}$ & Eigenvalue & Trace statistic & $\begin{array}{l}\text { Critical } \\
(5 \%)\end{array}$ & Value & p-value ** \\
\hline None & 0.1048 & 8.3109 & 15.495 & & 0.4328 \\
\hline At most one & 0.019 & 1.2275 & 3.8412 & & 0.2679 \\
\hline \multicolumn{6}{|c|}{ Unrestricted Cointegration Rank Test (Maximum Eigenvalue) } \\
\hline $\begin{array}{l}\text { Number of coin- } \\
\text { tegration vectors } \\
\text { under Ho }\end{array}$ & Eigenvalue & Trace statistic & $\begin{array}{l}\text { Critical } \\
(5 \%)\end{array}$ & Value & $\mathrm{p}$-value ${ }^{* *}$ \\
\hline None & 0.1048 & 7.0834 & 14.2646 & & 0.4793 \\
\hline At most one & 0.019 & 1.2275 & 3.8415 & & 0.2679 \\
\hline
\end{tabular}

Table 21 - Granger Causality Test ${ }^{a}$

\begin{tabular}{|c|c|c|c|}
\hline Null Hypothesis & Number of Obs. & F-statistic & p-value \\
\hline E does not Granger-Cause IPCA & 66 & 9.0601 & $5.0 \mathrm{E}-05$ \\
IPCA does not Granger-Cause E & & 1.4686 & 0.2323 \\
\hline
\end{tabular}

${ }^{a}$ It is important to include as many lags as possible in variable $\mathrm{x}$ that may be significant over variable $\mathrm{y}$. We tested an equation with 13 lags in both variables and the highest significant lag of $\mathrm{x}$ over $\mathrm{y}$ was the third lag of $\mathrm{E}$ over IPCA. In the Granger Causality test the null hypothesis that IPCA Granger-Causes E is rejected both with 3 and with 13 lags. 
Table 22 - VAR between E and IPCA

\begin{tabular}{|c|c|c|c|c|c|}
\hline Variables & $E$ & IPCA & Variables & E & IPCA \\
\hline $\mathrm{E}(-1)$ & $\begin{array}{l}0.6036 \\
(0.1217) \\
{[4.9597]}\end{array}$ & $\begin{array}{l}0.0356 \\
(0.0111) \\
{[3.201]}\end{array}$ & IPCA(-1) & $\begin{array}{l}0.9185 \\
-12.735 \\
{[0.7213]}\end{array}$ & $\begin{array}{l}0.6556 \\
(0.1163) \\
{[5.6392]}\end{array}$ \\
\hline $\mathrm{E}(-2)$ & $\begin{array}{l}-0.1168 \\
(0.1501) \\
{[-0.7780]}\end{array}$ & $\begin{array}{l}-0.0037 \\
(0.0137) \\
{[-0.2669]}\end{array}$ & IPCA(-2) & $\begin{array}{l}-2.704 \\
-15.498 \\
{[-1.7447]} \\
\end{array}$ & $\begin{array}{l}-0.2059 \\
(0.1415) \\
{[-1.4555]}\end{array}$ \\
\hline$E(-3)$ & $\begin{array}{l}0.1183 \\
(0.1239) \\
{[0.9547]}\end{array}$ & $\begin{array}{l}0.0220 \\
(0.0113) \\
{[1.9463]}\end{array}$ & IPCA(-3) & $\begin{array}{l}24.593 \\
-15.498 \\
{[1.5868]}\end{array}$ & $\begin{array}{l}0.1452 \\
(0.1415) \\
{[1.0260]}\end{array}$ \\
\hline $\mathrm{E}(-4)$ & $\begin{array}{l}0.0827 \\
(0.1033) \\
{[0.8007]}\end{array}$ & $\begin{array}{l}-0.0051 \\
(0.0094) \\
{[-0.5394]}\end{array}$ & IPCA(-4) & $\begin{array}{l}-25.399 \\
-11.504 \\
{[-2.2079]}\end{array}$ & $\begin{array}{l}0.06289 \\
(0.1050) \\
{[0.5988]}\end{array}$ \\
\hline $\mathrm{C}$ & $\begin{array}{l}0.01652 \\
(0.0084) \\
{[1.9756]} \\
\end{array}$ & $\begin{array}{l}0.0018 \\
(0.0008) \\
{[2.3730]}\end{array}$ & D2002_M11 & $\begin{array}{l}-0.135 \\
(0.0344) \\
{[-3.9256]}\end{array}$ & $\begin{array}{l}0.0143 \\
(0.0031) \\
{[4.5682]}\end{array}$ \\
\hline $\begin{array}{l}\text { R-squared } \\
\text { F-statistic }\end{array}$ & $\begin{array}{l}0.4582 \\
51.688\end{array}$ & $\begin{array}{l}0.7168 \\
154.665\end{array}$ & $\begin{array}{ll}\text { Adj. } & \text { R- } \\
\text { squared } & \end{array}$ & 0.3696 & 0.6704 \\
\hline
\end{tabular}

Note: Std. deviations in parenthesis and t-statistics in square brackets.

Table 23 - Variance Decomposition (Cholesky ordering: place E IPCA)

\begin{tabular}{|c|c|c|c|c|c|c|c|}
\hline \multicolumn{4}{|c|}{ Variance decomposition of E: } & \multicolumn{4}{c|}{ Variance decomposition of IPCA: } \\
\hline Period & Std. Error & E & IPCA & Period & Std. Error & E & IPCA \\
1 & 0.0306 & 100.000 & 0.0000 & 1 & 0.0028 & 30.385 & 969.616 \\
2 & 0.0356 & 994.964 & 0.5036 & 2 & 0.0034 & 71.131 & 928.869 \\
3 & 0.0370 & 982.151 & 17.849 & 3 & 0.0037 & 157.357 & 842.643 \\
4 & 0.0374 & 982.384 & 17.616 & 4 & 0.004 & 270.031 & 72.997 \\
5 & 0.0383 & 97.469 & 25.310 & 5 & 0.0042 & 323.807 & 676.193 \\
6 & 0.0391 & 954.898 & 45.102 & 6 & 0.0043 & 363.763 & 636.237 \\
77 & 0.0395 & 935.715 & 64.285 & 7 & 0.0044 & 392.664 & 607.336 \\
8 & 0.0397 & 928.832 & 71.168 & 8 & 0.0045 & 413.734 & 586.266 \\
9 & 0.0398 & 922.703 & 77.298 & 9 & 0.0046 & 423.243 & 576.758 \\
10 & 0.0400 & 917.409 & 82.591 & 10 & 0.0046 & 425.519 & 574.481 \\
11 & 0.0402 & 914.451 & 85.549 & 11 & 0.0046 & 424.477 & 575.523 \\
12 & 0.0403 & 913.992 & 86.008 & 12 & 0.0046 & 422.399 & 577.601 \\
\hline
\end{tabular}


Table 24 - OLS Equation for E

\begin{tabular}{ccccc}
\hline Variable & Coefficient & Standard Error & t-statistic & p-value \\
\hline C & 0.0059 & 0.0092 & 0.6378 & 0.5258 \\
AR(1) & 0.4341 & 0.0964 & 45.041 & 0.0000 \\
\hline R2 & 0.2351 & LM Test (1 lag) (a) & 0.8708 \\
Adjusted R2 & 0.2235 & ARCH-LM Test (1 lag) & 28.6673 (b) \\
\hline
\end{tabular}

Note: (a) null hypothesis of absence of autocorrelation accepted also for higher number of lags; (b) null hypothesis of absence of ARCH residuals rejected at $1 \%$.

Figure 15 - Exchange rate and inflation volatilities (reduced sample)

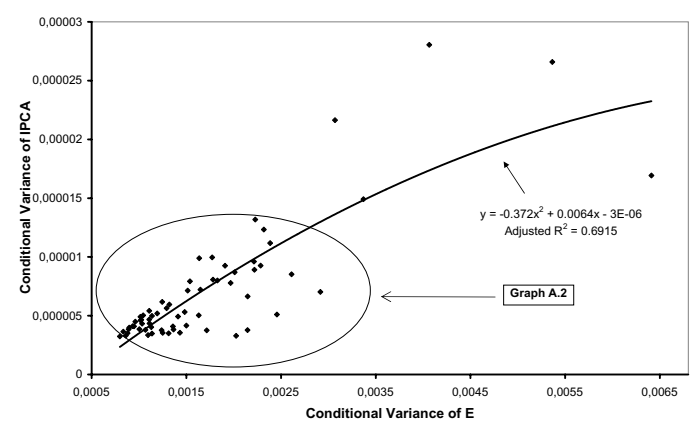

Figure 16 - Exchange rate and inflation volatilities (reduced sample)

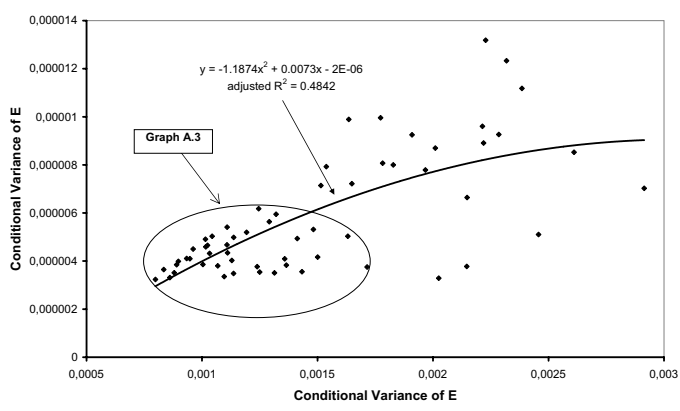

Figure 17 - Exchange rate and inflation volatilities (reduced sample)

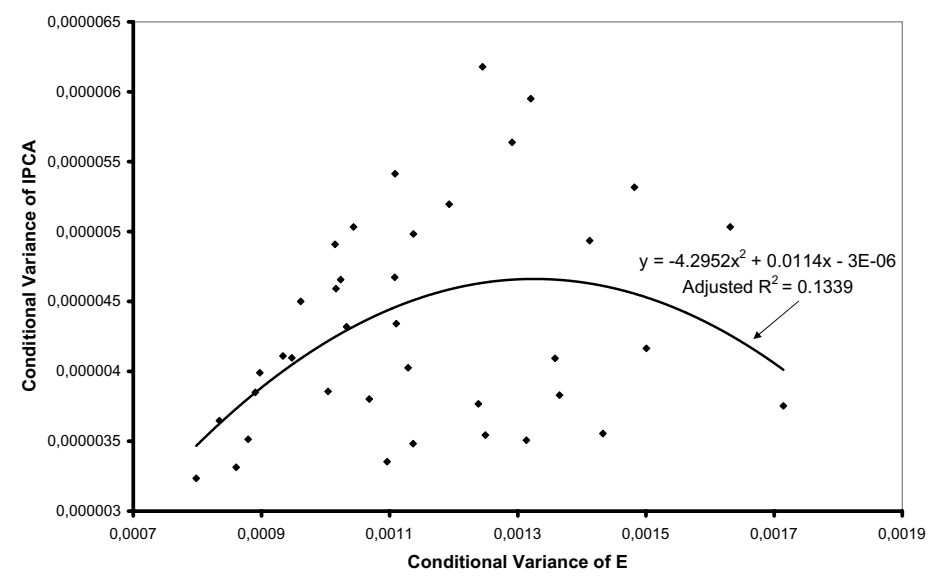




\section{B. DIAGNOSTIC TESTS FOR THE BI-GARCH MODEL}

This appendix brings a brief explanation about the test of covariance stationarity in the multivariate Garch model under the BEKK restriction. For details, see Engle and Kroner (1993).

In a bivariate GARCH $(1,1)$, the conditional variance has the form:

$$
\left[\begin{array}{l}
u_{11 t}^{2} \\
u_{12 t}^{2} \\
u_{22 t}^{2}
\end{array}\right]=\left[\begin{array}{l}
c_{11} \\
c_{12} \\
c_{22}
\end{array}\right]+\left[\begin{array}{lll}
B_{11} & B_{12} & B_{13} \\
B_{21} & B_{22} & B_{23} \\
B_{31} & B_{32} & B_{33}
\end{array}\right]\left[\begin{array}{l}
\sigma_{11(t-1)}^{2} \\
\sigma_{12(t-1)}^{2} \\
\sigma_{22(t-1)}^{2}
\end{array}\right]+\left[\begin{array}{lll}
A_{11} & A_{12} & A_{13} \\
A_{21} & A_{22} & A_{23} \\
A_{31} & A_{32} & A_{33}
\end{array}\right]\left[\begin{array}{l}
u_{11(t-1)}^{2} \\
u_{12(t-1)}^{2} \\
u_{22(t-1)}^{2}
\end{array}\right]
$$

Without exogenous variables, the BEKK restriction has the form:

$$
\begin{array}{r}
U_{t}=C_{1}^{*^{\prime}} C_{1}^{*}+\left[\begin{array}{cc}
B_{11}^{*} & B_{12}^{*} \\
B_{21}^{*} & B_{22}^{*}
\end{array}\right]^{\prime}\left[\begin{array}{cc}
\sigma_{1, t-1}^{2} & \sigma_{1, t-1} \sigma_{2, t-1} \\
\sigma_{2, t-1} \sigma_{1, t-1} & \sigma_{2, t-1}^{2}
\end{array}\right]\left[\begin{array}{cc}
B_{11}^{*} & B_{12}^{*} \\
B_{21}^{*} & B_{22}^{*}
\end{array}\right]+ \\
{\left[\begin{array}{cc}
A_{11}^{*} & A_{12}^{*} \\
A_{21}^{*} & A_{22}^{*}
\end{array}\right]^{\prime}\left[\begin{array}{ll}
U_{t-1}
\end{array}\right]\left[\begin{array}{cc}
A_{11}^{*} & A_{12}^{*} \\
A_{21}^{*} & A_{22}^{*}
\end{array}\right]}
\end{array}
$$

To assure the process is covariance stationary, the eigenvalues of $\sum_{i=1}^{q} \sum_{k=1}^{K}\left(B_{i k}^{*} \otimes B_{i k}^{*}\right)+\sum_{i=1}^{p} \sum_{k=1}^{K}\left(A_{i k} \otimes\right.$ $\left.A_{i k}\right)$ must be minor than the unity, in absolute values. In other words, we have to calculate the eigenvalue of matrix $\mathrm{X}$ below:

$$
X=\left[\begin{array}{cccc}
(a 11 * a 11)+(g 11 * g 11) & (a 11 * a 12)+(g 11 * g 12) & (a 12 * a 11)+(g 12 * g 11) & (a 12 * a 12)+(g 12 * g 12) \\
(a 21 * a 11)+(g 21 * g 11) & (a 11 * a 22)+(g 11 * g 12) & (a 12 * a 21)+(g 12 * g 21) & (g 12 * g 22)+(g 12 * g 21) \\
(a 21 * a 11)+(g 21 * g 11) & (a 21 * a 12)+(g 21 * g 12) & (a 22 * a 11)+(g 22 * g 11) & (a 22 * a 12)+(g 2 * g 12) \\
(a 21 * a 21)+(g 21 * g 21) & (a 21 * a 22)+(g 21 * g 22) & (a 21 * a 22)+(g 21 * g 22) & (a 22 * a 22)+(g 22 * g 22)
\end{array}\right]
$$

Calculating the eigenvalues of $\mathrm{X}$ using the coefficients for case 2 presented in table 3 along the text, we find the following vector y of eigenvalues:

$$
y=\left[\begin{array}{c}
0.6630 \\
-0.4252 \\
-0.0770 \\
0.0637
\end{array}\right]
$$

As we may see, all absolute values are minor than one. Hence, the case chosen respect the condition of covariance stationarity. 